\title{
As capitanias hereditárias no mapa de Luís Teixeira
}

\section{Jorge Pimentel Cintra ${ }^{1}$}

RESUMO: Partindo do conhecido mapa de Luís Teixeira, apresenta-se a evolução das capitanias hereditárias nos primeiros 50 anos. Constatou-se que esse mapa, apesar de seu valor histórico e cartográfico, possui diversos equívocos e inconsistências. Há enganos com relação às linhas divisórias, aos donatários e aos acontecimentos. Do ponto de vista cartográfico, como outros mapas da época, ele é suficientemente acurado em latitude, mas pouco em longitude. Com relação à datação, feita principalmente examinando-se os nomes dos donatários, pode-se dizer que coexistem dados de diferentes épocas, e a melhor explicação é de que o autor coletou dados numa época (1574) e depois atualizou algumas informações (1586), mas não todas. Para examinar essa questão, foi feita uma breve análise das vicissitudes desses territórios, cujas informações se encontram dispersas. Isso permitiu retificar alguns conhecimentos, como, por exemplo, o fato de a Capitania da Bahia, nos primeiros anos, ser formada unicamente pela cidade de Salvador, e que a categorização em vilas ou cidades não se dá pelo maior ou menor tamanho ou importância, mas pelo fato de serem criadas ou pelo donatário ou pela coroa. Esses enganos talvez possam ser explicados pelo caráter do mapa, comparável a alguns "roteiros" da época, e podem mostrar de forma concreta uma interessante lição já conhecida teoricamente: um mapa, por mais belo e histórico que seja, e por mais louvado que tenha sido, não pode ser considerado simploriamente como um retrato fiel da realidade, uma fotografia da época: como qualquer documento histórico, deve ser lido com cuidado e sentido crítico. PALAVRAS-CHAVE: Luís Teixeira. Capitanias hereditárias. Mapa das capitanias hereditárias. Cartografia histórica.

ABSTRACT: By means of the known map of Luis Teixeira, we analyze the evolution of the hereditary captaincies in their first 50 years. It was found that this map, despite its historical and cartographic value, has several mistakes and inconsistencies. There are errors with regard to the border lines, donatories and historical events. From the cartographic point of view, as other maps of the time, it is quite accurate in latitude but not in longitude. With regard to the dating, task made mainly by the examination of the names of the donatories, it can be said that coexist
1. Professor da Escola Politécnica da Universidade de São Paulo. E-mail: <jpcintra@usp.br>. 
2. Alguns grafam o nome do autor com z, outros com s, opção seguida no presente texto. Da mesma forma, diversos nomes foram atualizados pela grafia atual.

3. Ver Biblioteca da Ajuda (ms. 51-IV-38).

4. Ver Jaime Cortesão (1944, 1965).

5. Ver Avelino Teixeira da Mota \& Armando Cortesão (1960). data from different times and the best explanation for this is that the author collected the most data in 1574 and then updated some information in 1586, but not all. To examine this question, we made an analysis of the evolution of these territories, whose information are dispersed. And this propitiated rectify some knowledge; by example the fact that the Bahia captaincy, in the first years, be constituted only by the city of Salvador; and about the categorization of village or cities, that is not made in the base of the greater or lesser size or importance, but by the fact of be created by the donatory or by the crown. These mistakes may perhaps be explained by the character of the map, similar to some roteiros of the time, and show in a practical way an interesting lesson, yet known theoretically: a map, no matter how beautiful and how historical it is, it can not be considered as an accurate portrayal of the reality or as a photography of the time: as any historical document, should be read carefully and with critical sense.

KEY-WORDS: Luís Teixeira. Hereditary Captancies. Map of the Hereditary Captancies. Historical Cartography.

Introdução

Partindo e tendo como referência esse conhecido mapa de Luís Teixeira², o presente trabalho analisa também a evolução das capitanias hereditárias em seus primeiros 50 anos, isto é, de 1536 a 1586, data do atlas apenso à obra Roteiro de todos os sinais ${ }^{3}$. Inicia-se com uma breve consideração sobre o autor e uma análise geral do mapa e suas versões. A seguir, a análise da cartela permite adiantar algumas características do mapa e do modo de narrar de seu autor. A análise morfológica da costa constatou a boa precisão em latitude e os erros em longitude, comuns aos mapas da época, bem como os erros nas divisas entre as capitanias. Na sequência, através das vicissitudes desses territórios, estudou-se a questão da data em que o mapa foi produzido, constatando-se mais alguns enganos e omissões, como decorre da comparação com as demais plantas anexas ao Roteiro. Isso possibilitou retificar alguns conhecimentos, como, por exemplo, o fato de a Capitania da Bahia, nos primeiros anos, englobar unicamente a cidade do Salvador, e que a categorização em vilas e cidades, nesses inícios, não se dá por uma evolução, ou maior ou menor tamanho ou importância, mas pelo fato de serem criadas ou pelo donatário ou pela coroa.

Autor

Tanto Cortesão ${ }^{4}$ como Mota e Cortesão5 ${ }^{5}$ em obras clássicas, depois de considerarem a hipótese de autor anônimo, identificam Luís Teixeira como sendo - autor desse atlas. Luís Teixeira é qualificado como o último dos grandes cartógrafos portugueses, cuja atividade vai de meados do século XVI às duas primeiras décadas do século seguinte. Herdeiro da melhor tradição cartográfica da época, vê surgir uma nova hegemonia, a cartografia flamenga. Filho, pai, avô e bisavô de cartógrafos, formou escola. Recebeu sua carta de ofício em 1564, tendo sido examinado pelo célebre Pedro Nunes. Trabalhou como cartógrafo de Estado, o que seria um indício de méritos. 
Para a elaboração de seu atlas, esteve colhendo dados pessoalmente no Brasil, como se depreende de um escrito de Gaspar Reimão, piloto-mor do reino, datado de 1612. Desse escrito, Cortesão ${ }^{6}$ deduz que a coleta dos dados foi realizada em 1574. Como data mais provável para o mapa, aponta o ano de 1586, exatos 50 anos após a distribuição das últimas capitanias.

Em função dos elogios recebidos, da beleza e da antiguidade desse mapa, é se tentado a considerá-lo como um retrato fiel da realidade, uma fotografia do estado das capitanias nesse momento. Como se verá, essa consideração não se sustenta.

Atlas

A Biblioteca da Ajuda, antigo palácio real em Lisboa, possui em seu acervo um códice com o título: Roteiro de todos os sinaes, conhecim. tos, fundos, alturas e derrotas, que há costa do Brasil desde cabo de Santo Agostinho até o estreito de Fernão de Magalhães. Esse Roteiro é ilustrado de 13 cartas e plantas de cidades, coloridas e iluminadas, e como destaque cartográfico, ao final, apresenta o mapa ou atlas que comentamos (Figura 1).

As citadas obras clássicas realizam certa análise cartográfica da obra, que se completa pelas introduções e comentários de edições mais recentes do Roteiro7. Nossa leitura, no presente trabalho, obedece aos princípios explanados em Jorge Pimentel Cintra ${ }^{8}$.

Como se pode notar, o mapa possui uma extensa legenda no lado esquerdo superior, emoldurada em um quadro com múltiplas bordas, que não esconde alguns objetos que estão por baixo dele, concretamente a linha e os dizeres "tropico de capricornio".

Trata-se de um mapa geral da América Portuguesa cujo principal tema são as capitanias hereditárias, nomeadas pelo donatário ou capitão de cada uma, coisa que não é o ideal, pois as diversas divisões territoriais passaram por muitas mãos em pouco tempo - herdeiros diretos ou colaterais, compradores - introduzindo uma intensa dinâmica de nomes, o que torna qualquer mapa desatualizado em pouco tempo. Seria menos sujeito a mudanças, e mais propício à memorização, designar as capitanias por seus nomes, que foram mais duradouros ao longo do tempo.

$\bigcirc$ mapa cobre uma região que vai do Cabo do Norte, próximo à foz do Amazonas, até o estreito de Magalhães. Em latitude, abrange de $+3^{\circ}$ a $-56^{\circ}$; isso resulta em $59^{\circ}$ de extensão nessa coordenada; sabendo que as dimensões do mapa são 337 × 503 mm, pode-se calcular sua escala, que resulta em $1: 13.000 .000$ aproximadamente, tratando-se, portanto, de um mapa de pequena escala9 ${ }^{9}$, próprio de um atlas. Em longitude tem como limite a leste, aproximadamente, o meridiano da ilha de Ascensão, e a oeste, o meridiano da Terra do Fogo acidentes geográficos presentes no mapa.

Trata-se de um manuscrito, de bom acabamento e bom uso das cores: marrom-dourado nas molduras em geral, cartela e escala gráfica; vermelho na escala de meridianos, rosa dos ventos, como separador das linhas na cartela e em
6. Ver Jaime Cortesão (1965).

7. Ver Max Justo Guedes (1968) e Melba F. Costa (1988).

8. Ver Jorge Pimentel Cintra (2012, 2015).

9. A conta se faz dividindo a extensão em latitude no mapa, 0,503 $\mathrm{m}$, por essa mesma grandeza na realidade, $59^{\circ}$, multiplicados pela extensão de $1^{\circ}$, que é $110 \mathrm{~km}$. 


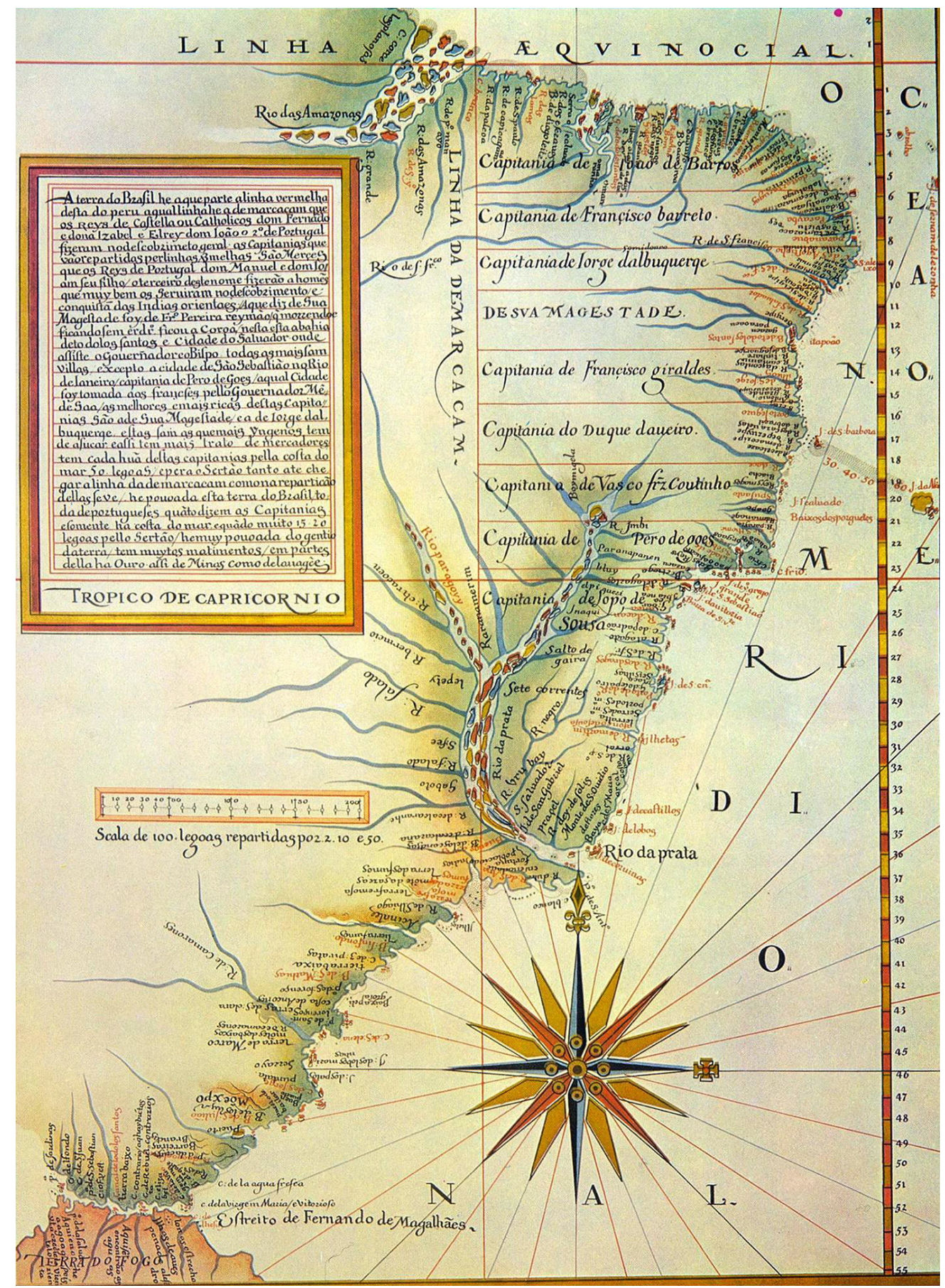

Figura 1 - Mapa de Luís Teixeira, anexo ao Roteiro de todos os Sinaes. Fonte: Biblioteca da Ajuda, Lisboa. Cópia elaborada a partir do original, ms. 51 -IV-38. 
algumas ilhas e nomes; o azul, em diferentes tons, para os oceanos e os rios. $\bigcirc$ tom esverdeado em toda a região costeira e nas margens de alguns rios dá uma impressão de sombreado e transmite a sensação de fertilidade das terras. Uma bela e trabalhada rosa dos ventos, no Atlântico Sul, faz lembrar os portulanos, com diversas linhas de rumos correndo em todas as direções. Não sendo tão rico como o atlas Miller, poderia, no entanto, servir de presente a príncipes.

$\bigcirc$ tipo e o desenho das letras (um compromisso entre a "humanística" do Quinhentos e a chamada "bastarda italiana" do dezesseis) são muito cuidados, e alternam-se nomes em preto e vermelho para facilitar a legibilidade. A maioria dos nomes na costa está de ponta cabeça, possibilitando que o topônimo comece a ser escrito na costa e avance para dentro do continente sem limite de espaço; caso contrário o cartógrafo teria que avaliar muito bem o tamanho dos nomes para que não invadissem o oceano, ultrapassando a linha costeira.

A toponímia é muito abundante: mais de 190 nomes ao longo da costa, cerca de 20 no Atlântico e mais de 30 rios nomeados no interior do continente. Isso representa mais que o dobro de informação do mapa de Diogo Homem, de 1558; o que reflete o progressivo conhecimento da costa e do interior, sendo que um particular progresso se dá na bacia do alto Paraná. A limitação dos nomes é, no entanto, uma questão de espaço: pode-se dizer que nessa escala e para manter a legibilidade, não há espaço para mais nomes ao longo da costa. Alguns topônimos, na região de Castela, estão escritos na língua correspondente; isso, e o próprio fato de constarem do mapa, levou Jaime Cortesão à dedução de que são informações do período filipino, posteriores, portanto, a 1580, quando eram facilitadas e transitavam em Portugal.

Alguns traçados são de certa forma genéricos e conceituais, no sentido de que transmitem conceitos e não uma realidade cartográfica específica, como se nota nas margens duplas de alguns rios, ou nos arquipélagos do Amazonas, Paraná e Paraguai: querem significar rios largos e muitas ilhas, mais que uma largura específica ou ilhas concretas.

Além do equador e do trópico, consta também a linha de demarcaçam (a de Tordesilhas), que, como em outros mapas da época, passa pela foz do Amazonas e do Prata, sendo que neste atlas avança um pouco mais, até a Baia de São Matias, tal como consignam em suas obras Gabriel Soares de Sousa e Frei Vicente do Salvador ${ }^{10}$.

Além da barra graduada de longitudes, há uma escala gráfica abaixo da cartela. Comparando-se as duas verifica-se que as divisões são de igual tamanho, ou seja, o mapa possui a mesma escala em latitude e longitude, indicando a intenção do cartógrafo de estabelecer uma projeção do tipo Carta Plana Quadrada, facilitando o registro do mapa em um programa de cartografia digital e assim extrair coordenadas e avaliar a precisão, como se fará mais adiante.

Vale a pena dizer que existem muitas versões desse mapa. $\bigcirc$ original, até certo tempo atrás, era reconhecido pelo fato de notarem-se as dobraduras (Figura 2) ao longo de 2 linhas verticais e uma horizontal, podendo se ver alguns
10. Ver Gabriel Soares de Sousa (1971 [1587], p. 6) e Frei Vicente do Salvador (1965 [1627], p. 18). 
rasgões de certo porte na costa brasileira, na cartela e na altura da rosa dos ventos. Recentemente o mapa foi restaurado, com muito cuidado, e não difere muito da versão da Figura 1.

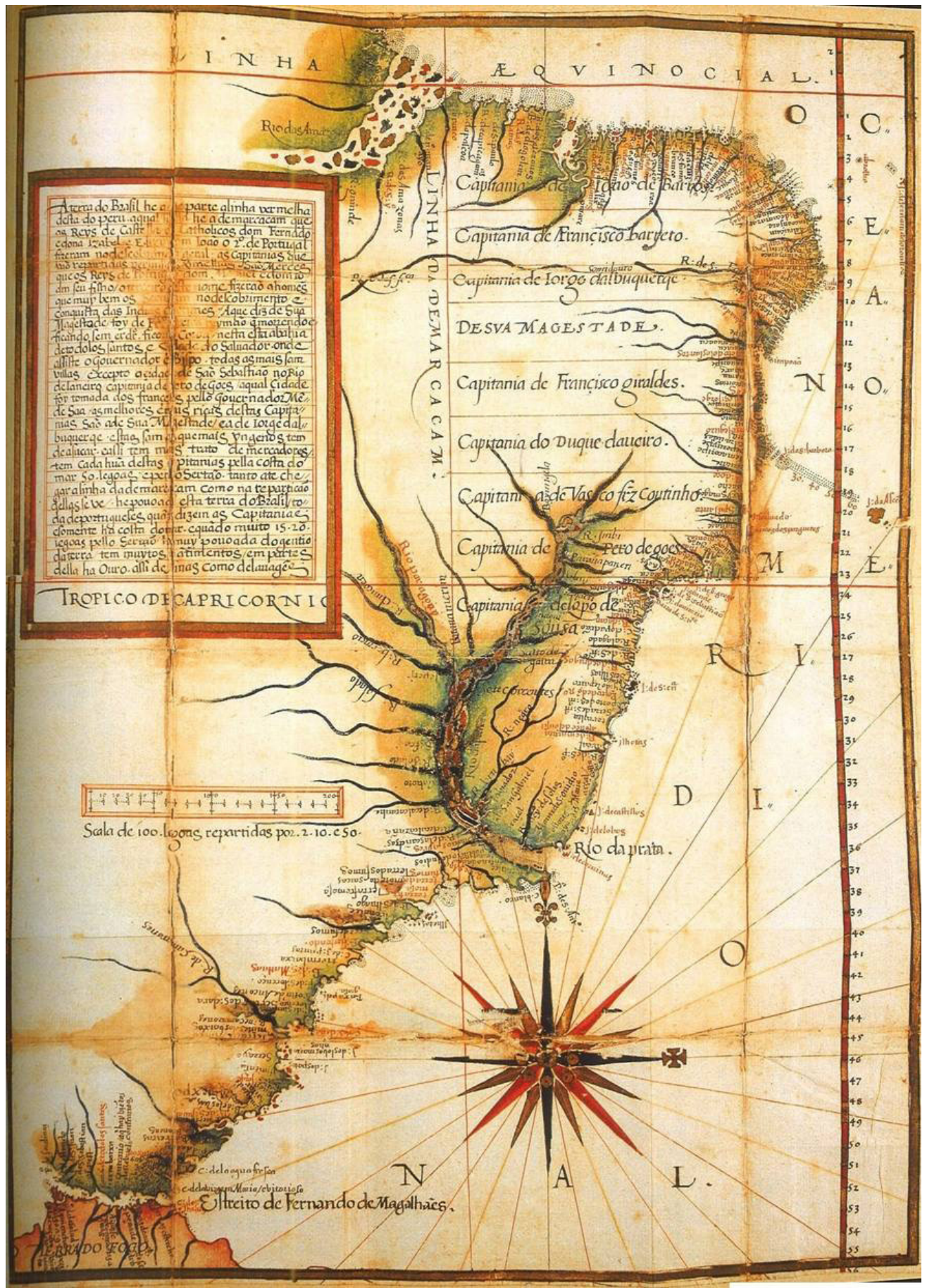

Figura 2 - Mapa de Luís Teixeira, original antes da restauração, notando-se as dobras. 
Algumas medições sobre esse mapa e sobre suas cópias mostraram que estas últimas foram benfeitas e que se pode trabalhar sobre elas para efeito de calcular latitudes e longitudes. Os copistas também interpretaram, de maneira geral, com fidelidade a toponímia.

Em função disso, as cores e seus matizes variam de versão para versão, e o atlas se transformou em um símbolo, sendo utilizado para ilustrar e até para abrir livros de História do Brasil, como por exemplo o de Frei Vicente do Salvador. Na 5. a edição notam-se mais claramente os tons dourados e avermelhados do original. A melhor reprodução, em bom tamanho e cores, é a que figura na obra de Carlos Dias ${ }^{11}$. Sem dúvida, tornou-se um ícone para falar das capitanias hereditárias, como um mapa de época. Também aparece em livros didáticos e sites sobre o tema. Afinal, é o primeiro em que essas linhas divisórias foram desenhadas.

A cartela e o caráter desse mapa

Otexto dessa cartela é muito rico em informações e ajuda a compreender o caráter, a linguagem (discurso) e o tipo desse mapa. Apresenta-se a seguir uma transcrição paleográfica, introduzindo somente a pontuação, para que se entenda melhor e, inserindo alguns números para posterior comentário. Diz o texto da cartela, transcrito linha a linha, em correspondência com o original:
11. Ver Carlos Malheiro Dias (1921, lâmina entre as páginas 256 e 257). 
12. Ver Francisco Adolfo Varnhagen (1956, v. I, p. 237) e a nota de Capistrano de Abreu. O documento, uma carta de juro que constituía um morgado, foi passada em 16 de agosto de 1576 .

13. Cf. Francisco Adolfo Varnhagen (1956, v. I, p. 307).

\author{
mar 50 legoas (7) e pera o sertão tanto ate che \\ gar a linha da demarcaçam como na repartição \\ dellas se ve / he povoada esta terra do Brasil to \\ da de portugueses (8) quãto dizem as capitanias \\ e somente ha costa de mar, e quãto muito 15 a 20 \\ legoas pello Sertão/ he muy povoada do gentio \\ da terra/tem muytos matimentos/Em partes \\ della ha Ouro assi de Minas como de lavagēes.
}

Comentam-se a seguir as passagens marcadas com numeração nesse texto, que indica não somente erros ou imprecisões de linguagem, mas também esclarecimentos, na certeza de que se aprende mais com a procura dos motivos do erro do que com a constatação dos acertos.

A expressão "fizeram no descobrimento geral" (1) é ambígua, no sentido de que o acerto da linha de demarcação foi feito antes de todas as terras serem descobertas, particularmente das regiões representadas nesse mapa. É, no entanto, correta se interpretarmos que fizeram uma demarcação ou repartição geral das terras - descobertas e por descobrir.

A frase que termina citando D. Manuel e D. João (2) está incorreta, pois as doações, repartidas por meio das linhas vermelhas, são devidas só a D. João $3^{\circ}$. D. Manuel fez a doação da capitania da ilha de São João a Fernando de Noronha, mas essa não vai repartida em linhas vermelhas como consta no texto.

No trecho (3), o nome correto do antigo donatário da capitania é Francisco Pereira Coutinho e não $\mathrm{Fr}^{\circ}$ (Francisco) Pereira Reymão. Ele acerta o nome e o primeiro sobrenome, mas se equivoca ao acrescentar o sobrenome Reimão, comum na época, como era o do já citado Gaspar Ferreira Reymão, piloto-mor do reino na época de Luís Teixeira.

A expressão indicada em (4), "ficando sem herdeiro, ficou a coroa", precisa de um acerto: ficou para a coroa, ou ficou com ela a coroa. Mas o erro consiste em que a capitania não ficou para a coroa pela falta de herdeiros: Manuel Coutinho, filho do donatário (portanto não morreu sem herdeiros), cedeu a capitania ${ }^{12}$ à coroa por quatrocentos mil réis de juro por ano, a serem pagos, para si e seus herdeiros, pela redizima - imposto previsto na carta de doação. Ou seja, a coroa comprou a capitania, ainda que tardiamente.

No trecho (5), o erro consiste em que a cidade do Rio de Janeiro ficava na Capitania de Martim Afonso de Sousa (primeiro lote) e não na de Pero de Góis. Mas de fato se cogitou seriamente na implantação de uma cidade no Espírito Santo, ainda que pouco tempo depois Mém de Sá advogava por "fundar outra cidade real no sul do Brasil (...) [insistindo] pela colonização do Rio de Janeiro, a fim de que (...) houvesse outra cidade salvadora destas paragens"13.

No trecho (6), o que foi tomado aos franceses foi simplesmente o local, onde depois se edificou uma povoação, depois transferida e elevada à condição de cidade. Ainda que, a 1. de março de 1565, Estácio de Sá, em sua proclamação 
de ânimo e coragem aos combatentes, profetiza a vitória, a conquista do território e a fundação de uma "cidade", que viria a ser "a rainha das províncias e o empório das riquezas do mundo". Profecia que se cumpriu de certa forma e que lembra a arenga que Shakespeare poria anos mais tarde na boca de Henrique V na véspera da batalha de Azincourt. Em resumo, representando Mém de Sá, Estácio tomou a região em que seria edificada logo mais a cidade do Rio de Janeiro. ${ }^{14}$

No trecho (7) há uma generalização, nem todas as capitanias tinham 50 léguas de costa - de 12, somente 4 possuíam essa medida (no papel) encontramos outras com: 100, 80, 75, 60, 40, 35 e 30 léguas. Mas, de fato, a medida básica que o rei pensou e comunicou a Martim Afonso foi a de 50 léguas. Depois, o próprio Martim Afonso recebe duas medidas, 100 léguas, seu irmão recebe 50 e um adicional de 30, João de Barros e Aires da Cunha recebem primeiramente 50 e depois um complemento de 25 e Pero de Góis fica com 30, naquilo que sobrou das divisões.

Otrecho (8) é interessante, pois o cartógrafo parece querer dizer que, embora o soberano seja um monarca estrangeiro, a terra é habitada somente por portugueses. E, de fato, por que num mapa da cartografia portuguesa se representam terras de Castela, com abundantes detalhes e toponímia? A união ibérica explicaria essa reunião de cartografias, com igual densidade de topônimos, num só mapa. No entanto, a linha demarcatória permanece firme.

Depois desses comentários, não há como negar que a redação da cartela possui suas deficiências, se quisermos julgar as coisas do ponto de vista de "informações exatas e precisas", ainda mais se comparadas com dados que possuímos hoje. Pode-se então pensar que esse texto reflete o conhecimento comum da época, notícias difundidas, mas não comprovadas com o recurso a documentos originais, a fontes, como poderiam ser as cartas de doação. Talvez não estivessem mesmo disponíveis. De certa forma, quanto ao estilo, não só a cartela como também o mapa possuem certa semelhança com nossas primeiras histórias, de concreto as de Frei Vicente do Salvador e Gabriel Soares de Sousa, que consultam diversos textos disponíveis em sua época, mas não fontes primárias.

Análise morfológica da costa brasileira

Para analisar a precisão do mapa, realizamos o estudo das precisões de suas coordenadas por meio da metodologia indicada anteriormente ${ }^{15}$. $\bigcirc$ resultado vem expresso na Tabela 1 , e se comenta na sequência.

Tabela 1 - Análise da qualidade das coordenadas do mapa de Luís Teixeira

\begin{tabular}{|c|c|c|c|c|c|c|c|c|}
\hline \multirow[b]{2}{*}{ N. ${ }^{\circ}$} & \multirow[b]{2}{*}{ LOCAL NO MAPA } & \multirow[b]{2}{*}{ LOCAL ATUAL } & \multicolumn{2}{|c|}{ MAPA } & \multicolumn{2}{|c|}{ ATUAL } & \multicolumn{2}{|c|}{ DIFERENÇAS } \\
\hline & & & $\lambda \mathrm{m}$ & $\varphi \mathrm{m}$ & $\lambda \mathbf{a}$ & $\varphi \mathbf{a}$ & $\Delta \lambda$ & $\Delta \varphi$ \\
\hline 1 & Sem nome & Ponta da Tijioca & 53,10 & 0,00 & 48,05 & $-0,66$ & 5,05 & 0,66 \\
\hline 2 & B. de Diogo Leite & Rio Turiassú & 49,47 & $-0,88$ & 45,25 & $-1,64$ & 4,22 & 0,76 \\
\hline 3 & o maranhã & Baía de São Luis & 47,34 & $-1,78$ & 44,68 & $-2,77$ & 2,67 & 0,99 \\
\hline
\end{tabular}

Annals of Museu Paulista. v. 23. n.2. Jul.-Dec. 2015.
14. Cf. Theresinha de Castro (1968, p. 65-66).

15. Ver Jorge Pimentel Cintra (2012). 


\begin{tabular}{|c|c|c|c|c|c|c|c|c|}
\hline 4 & r primeiro & Rio Jundiaí & 37,22 & $-4,62$ & 35,20 & $-5,75$ & 2,02 & 1,12 \\
\hline 5 & Sem nome & Cabo branco & 36,31 & $-5,85$ & 34,93 & $-6,87$ & 1,38 & 1,02 \\
\hline 6 & baia da treiçam & Baia da Traição & 35,47 & $-6,30$ & 34,93 & $-6,68$ & 0,54 & 0,38 \\
\hline 7 & Parayba & Rio Paraíba (Cabedelo) & 35,46 & $-6,76$ & 34,85 & $-6,96$ & 0,61 & 0,20 \\
\hline 8 & I de tamaracá & llha de Itamaracá & 35,11 & $-8,07$ & 34,86 & $-7,75$ & 0,25 & $-0,32$ \\
\hline 9 & Villa dolinda & Olinda & 34,86 & $-8,37$ & 34,86 & $-7,81$ & 0,00 & $-0,56$ \\
\hline 10 & $R$ de S Fco & Rio de São Francisco & 36,64 & $-10,31$ & 36,40 & $-10,50$ & 0,24 & 0,19 \\
\hline 11 & B de todos los Santos & Baia de Todos os Santos & 38,14 & $-13,00$ & 38,81 & $-13,14$ & $-0,67$ & 0,14 \\
\hline 12 & S Antonio & Rio Pardo & 37,87 & $-15,46$ & 38,95 & $-15,65$ & $-1,08$ & 0,19 \\
\hline 13 & R Doce & Rio Doce & 38,47 & $-18,20$ & 39,56 & $-18,09$ & $-1,09$ & $-0,11$ \\
\hline 14 & Porto Seguro & Porto Seguro & 38,62 & $-18,38$ & 39,07 & $-18,38$ & $-0,45$ & 0,00 \\
\hline 15 & Baixo dos Porgudos & Rio Itapemirim & 38,99 & $-20,84$ & 40,81 & $-21,00$ & $-1,82$ & 0,16 \\
\hline 16 & C Frio & Cabo Frio & 39,30 & $-23,02$ & 42,00 & $-23,00$ & $-2,70$ & $-0,02$ \\
\hline 17 & Barra de S Vte. & São Vicente & 43,27 & $-24,10$ & 46,38 & $-23,96$ & $-3,11$ & $-0,13$ \\
\hline 18 & Rio da cananea & Cananéia & 44,07 & $-25,02$ & 47,93 & $-25,01$ & $-3,86$ & $-0,01$ \\
\hline 19 & I de S. Cta. & Santa Catarina & 44,35 & $-28,16$ & 48,55 & $-27,59$ & $-4,19$ & $-0,58$ \\
\hline 20 & C de S Maria & Cabo de Santa Maria & 47,34 & $-34,92$ & 55,00 & $-35,00$ & $-7,66$ & 0,08 \\
\hline 21 & Monte de S Ovidio & Montevidéu & 49,46 & $-35,77$ & 56,26 & $-34,89$ & $-6,80$ & $-0,88$ \\
\hline & & & & & \multicolumn{2}{|c|}{ MÉDIA } & $-0,78$ & 0,16 \\
\hline & & & & & \multicolumn{2}{|c|}{ DESVIO } & 3,20 & 0,53 \\
\hline
\end{tabular}

Foram tomados 21 pontos ao longo da costa, de tal forma que estivessem regularmente espaçados e nos quais pudesse ser determinada a correspondência entre o local nesse mapa e num mapa atual. Utilizando um programa de cartografia digital foi feito o registro desse mapa, na projeção Carta Plana Quadrada, como determinada anteriormente. Como ele não possui escala de longitudes, fixou-se a longitude de Olinda no valor atual, resultando em erro nulo nesse ponto.

Na tabela 1, $\lambda$ e $\varphi$ correspondem a longitude e latitude e os índices $m$ e a correspondem aos valores dessas coordenadas no mapa em estudo e num mapa atual. As duas últimas colunas, das diferenças, são o resultado final que permite a análise.

Em longitude verifica-se um erro positivo que vai aumentando de Olinda ao longo da costa para o norte e depois para oeste, atingindo o valor máximo de $5^{\circ}$ na Ponta da Tijioca, nas proximidades de Belém. Reflete a conhecida distensão da costa leste-oeste, comum em todos os mapas produzidos pelo menos até 1750, sendo o Mapa das Cortes emblemático desse fato. Por outro lado, em direção ao sul, verifica-se um erro negativo que vai crescendo até cerca de $7,7^{\circ}$ na altura do cabo de Santa Maria. Essas diferentes distensões fazem com que a linha de Tordesilhas, relativamente correta ao norte (próxima à Iha de Marajól não passe por Laguna e sim avance para dentro do continente, passando pelo golfo de São Matias. A média dessa coordenada indica que há 
um erro sistemático $\left(-0,78^{\circ}\right)$, devido à escolha dos pontos (mais pontos ao sul do que ao norte de Olinda). $\bigcirc$ desvio padrão $\left(3,2^{\circ}\right)$ é uma medida da precisão, que não sendo boa para os tempos atuais, situa-se em nível compatível com a de outros mapas da época.

Já em latitude, os portugueses, possuíam técnicas mais apuradas de medição, com o emprego do astrolábio, cujo limite se situava em torno de $0,5^{\circ}$, como constata-se também nesse mapa, com a precisão de 0,53․ Há um erro sistemático nessa coordenada, mas desprezível $\left(0,16^{\circ}\right.$. Em resumo, o resultado nessa coordenada é muito bom, também examinando os pontos individualmente; e se eliminássemos os pontos 4, 5 e 21 , que estão um pouco piores, o resultado geral seria melhor: $0,11^{\circ}$ para a média e $0,41^{\circ}$ para o desvio.

Devido a esse tipo de projeção, as deformações se acentuam quando a latitude se aproxima do pólo. Foi feita então uma análise do ponto médio do estreito de Magalhães, e resultou estar com um erro relativamente pequeno: em torno de $1^{\circ}$, tanto em latitude como em longitude. De forma semelhante, o cálculo da extensão do final do continente e da Terra do Fogo resultou em $6^{\circ}$, contra 5, $5^{\circ}$ da realidade. Ou seja, a deformação, que visualmente parece exagerada, quando se compara essa morfologia com a que estamos habituados a ver, não é tão grande assim quando se efetuam os cálculos matemáticos.

Para visualizar as diferenças morfológicas da costa brasileira nesse mapa, elaborou-se a Figura 3 em que, em vez de analisar erros em locais pontuais, como na Tabela 1, mostrou-se essa diferença de forma contínua. Para isso, por meio da cartografia digital, a costa brasileira foi superposta a esse mapa, na mesma projeção cartográfica, impondo-se a coincidência em Olinda, já que o mapa não está graduado em longitude.

Nessa figura pode-se ver em vermelho o contorno do Brasil e a linha de Tordesilhas, passando pela ilha de Marajó e por Laguna, conforme os cálculos mostrados anteriormente ${ }^{16}$. Mas todo o conjunto está mais curto que a costa no mapa de Teixeira, em função da conhecida distensão. Com relação aos pontos no litoral, a longitude está correta em Olinda, por imposição, mas também em São Vicente. Entre esses pontos a distorção situa-se em torno de $1^{\circ}$, atinge $2^{\circ} \mathrm{em}$ Cabo Frio e vai a $4^{\circ}$ em Laguna, situando-se o mapa a leste da posição real. Ao norte, a costa leste-oeste está ampliada e a distensão máxima é de $5^{\circ}$, nas proximidades de Belém, situando-se o mapa a oeste da posição real. Unindo Belém com Laguna, no mapa de Luís Teixeira, tem-se uma linha de Tordesilhas inclinada, desenhada em verde no mapa.

\section{Análise das linhas divisórias das capitanias}

Tendo em conta a boa precisão desse mapa em latitude, seria de esperar que as linhas demarcatórias entre capitanias, que correm todas segundo paralelos nesse mapa, estivessem corretamente representadas, correspondendo à divisa definida na carta de doação. Para examinar essa questão foi montada a Tabela 2.
16. Ver Jorge Pimentel Cintra (2013). 


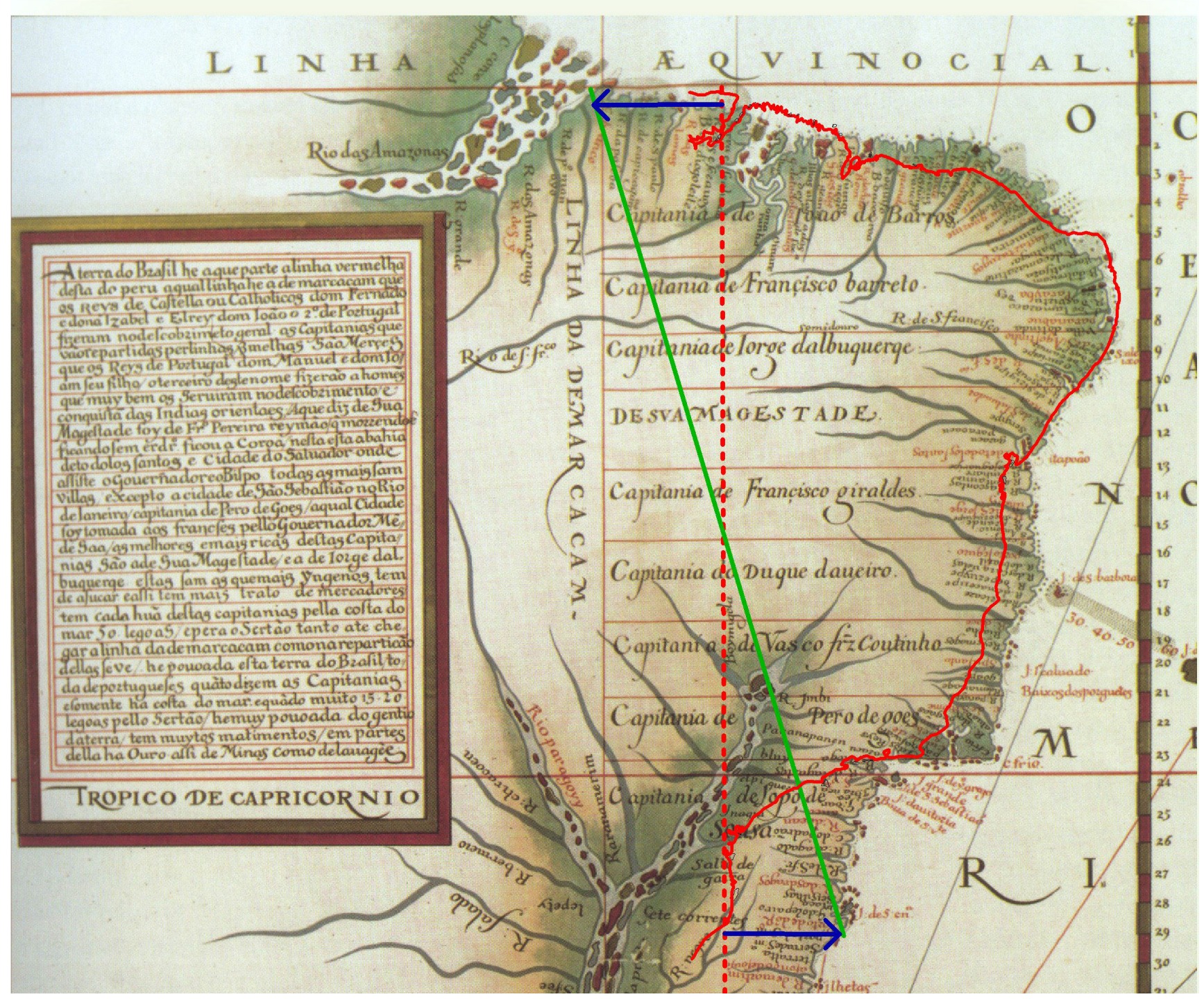

Figura 3 - Costa brasileira e Linha de Tordesilhas sobre o mapa de Luís Teixeira, elaborado pelo autor sobre o mapa original da Biblioteca da Ajuda.

17. Ver Jorge Pimentel Cintra (2012).
Para montar essa Tabela, fizemos novo registro do mapa e extraímos as coordenadas dos pontos fronteiriços e anotamos também o local, ou local mais próximo no mapa, e obtivemos as coordenadas dos pontos definidos nas cartas de doação por meio de um mapa atual, segundo a metodologia indicada anteriormente ${ }^{17}$.

Na coluna limites colocamos o local extraído do mapa e o local correto, definido nas cartas de doação ou acordado entre os donatários. 
Tabela 2 - Estudo da precisão dos limites das capitanias

18. Cf. Bartolomeu Velho (1561).

\begin{tabular}{|c|c|c|c|c|c|c|c|c|c|}
\hline \multirow[t]{2}{*}{ N. ${ }^{\circ}$} & \multirow[t]{2}{*}{ CAPITANIA } & \multicolumn{2}{|c|}{ LIMITES } & \multicolumn{2}{|c|}{ MAPA } & \multicolumn{2}{|c|}{ MAPA ATUAL } & \multicolumn{2}{|c|}{ DIFERENC̣AS } \\
\hline & & LUÍS TEIXEIRA & REAL & $\lambda m$ & $\varphi m$ & $\lambda a$ & $\varphi \mathbf{a}$ & $\Delta \lambda$ & $\Delta \varphi$ \\
\hline 1 & João de Barros & R.de Camaratibe & $\begin{array}{l}\text { Baia da } \\
\text { Traição }\end{array}$ & $-36,44$ & $-5,82$ & $-34,93$ & $-6,68$ & $-1,51$ & 0,86 \\
\hline 2 & $\begin{array}{l}\text { Francisco } \\
\text { Barreto }\end{array}$ & $\begin{array}{l}\text { Villa dolinda } \\
\text { (prox.) }\end{array}$ & $\begin{array}{l}\text { I. de } \\
\text { Itamaracá }\end{array}$ & $-35,02$ & $-8,39$ & $-34,85$ & $-7,81$ & $-0,17$ & $-0,58$ \\
\hline 3 & $\begin{array}{l}\text { Jorge } \\
\text { Albuquerque }\end{array}$ & R de S. Fco. & (ldem) & $-36,78$ & $-10,30$ & $-36,40$ & $-10,50$ & $-0,38$ & 0,20 \\
\hline 4 & $\begin{array}{l}\text { De sua } \\
\text { majestade }\end{array}$ & $\begin{array}{l}\text { B de todos los } \\
\text { Santos }\end{array}$ & (Idem) & $-38,28$ & $-13,06$ & $-38,81$ & $-13,14$ & 0,53 & 0,08 \\
\hline 5 & $\begin{array}{l}\text { Francisco } \\
\text { Giraldes }\end{array}$ & S Antonio & Rio Pardo & $-37,99$ & $-15,49$ & $-38,95$ & $-15,65$ & 0,96 & 0,16 \\
\hline 6 & Duque daveiro & R doce & Rio Mucuri & $-38,63$ & $-18,31$ & $-39,56$ & $-18,09$ & 0,93 & $-0,22$ \\
\hline 7 & $\begin{array}{l}\text { Vasco Frz } \\
\text { Coutinho }\end{array}$ & R de manage & $\begin{array}{l}\text { Rio } \\
\text { Itapemirim }\end{array}$ & $-39,04$ & $-20,84$ & $-40,81$ & $-21,00$ & 1,77 & 0,16 \\
\hline 8 & Pero de Goes & C frio & Rio Macaé & $-39,37$ & $-23,06$ & $-41,78$ & $-22,38$ & 2,41 & $-0,68$ \\
\hline 9 & Lopo de Sousa & $\begin{array}{l}\text { Monte de S } \\
\text { Ovidio }\end{array}$ & Montevideo & $-49,46$ & $-35,77$ & $-56,26$ & $-34,89$ & 6,79 & $-0,88$ \\
\hline & & & & & & & & 0,57 & 0,00 \\
\hline & & & & & & DES & 10 & 1,25 & 0,49 \\
\hline
\end{tabular}

Analisando o próprio mapa, confirmado pela Tabela 2, verifica-se que há um erro de local nos limites 1, 2 e 8 , pelo menos. Isso porque a Baia da Traição aparece no mapa e a linha não parte daí; a linha 2 não parte das proximidades de Olinda (ltamaracá não figura no mapa) e a linha 8 não parte do Cabo Frio, mas 13 léguas ao norte (Rio Macaé, que não figura no mapa). Ao sul, a última capitania (Terras de Santana) chegava somente até a latitude de $28^{\circ} 1 / 3$, onde deveria constar um limite; a partir daí o cartógrafo deveria assinalar: "De sua majestade", ou "Del Rey Nosso Senhor", como faz o mapa de Bartolomeu Velho ${ }^{18}$. Para os demais locais, embora em alguns haja uma discordância de topônimos, a pequena diferença em latitude leva à conclusão de que há um acerto na linha. Acrescentamos Montevidéu só para indicar aproximadamente o local em que o mapa coloca os limites ao sul. Mas não incluímos esses dados nos cálculos. Em termos de análise, os grandes erros em latitude aparecem nos locais onde houve erro de identificação: 1, 2 e 8. Em latitude, o comportamento dos erros obedece primordialmente aos erros do mapa, conforme mostrado na Figura 3. 
19. Ver Jaime Cortesão (1944, 1965) e Avelino Teixeira da Mota \& Armando Cortesão (1960).

20. Consta nesse mapa, como de fato há, uma extensa zona de baixios unindo a Ilha de Santa Bárbara $\left(17^{\circ}\right.$ de latitude $)$ à da Ascensão $\left(20^{\circ}\right.$ de latitude), marcando-se inclusive a profundidade em braças.
O engano na capitania atribuída a Francisco Barreto (ltamaracá) poderia ter sua origem na informação que o autor insere na cartela: a de que todas as capitanias teriam 50 léguas de extensão ao longo da costa. Assim, medindo sobre o mapa, a Capitania de Itamaracá (Francisco Barreto) possui 52 léguas de extensão, e a de Pernambuco (Jorge de Albuquerque), umas 50; enquanto na carta de doação a primeira possuía 30 léguas (de fato, 20) a e a segunda 60 (de fato, 52). Itamaracá, a menor faixa de terra, aparece grandemente aumentada.

Outra incorreção, talvez insanável para esse cartógrafo, é a linha divisória que sai de Cabo Frio (devendo sair de Macaé), que na carta de doação de Pero de Góis corre direto para oeste e na carta de Martim Afonso segue o rumo de noroeste até encontrar o paralelo de $21^{\circ}$ e daí segue esse paralelo, formando uma capitania triangular.

Por que teria havido esses erros? Provavelmente porque o cartógrafo não teve acesso às cartas de doação e desenhou as linhas de acordo com aquilo que era de conhecimento geral, com algumas informações corretas e outras não. Mas chama a atenção que um cartógrafo real, do porte de Luís Teixeira, não tivesse acesso ou não se preocupasse com a exatidão das informações sobre os limites geográficos das divisões políticas, principal tema de seu mapa.

A questão da datação e mais alguns enganos

Cortesão (1944, 1965) e Mota e Cortesão (1960) começam afirmando que esse mapa é sem dúvida do último quartel do Quinhentos ${ }^{19}$. Mas a datação mais precisa causou e continua causando dores de cabeça. A tentativa é feita analisando-se registros externos e internos ao próprio mapa. Com relação aos primeiros, existe a informação de que o autor esteve no Brasil no tempo do governador Luís de Brito e Almeida, percorrendo a costa, sondando os baixios nas vizinhanças da itha da Ascensão ${ }^{20}$ e recolhendo outros dados cartográficos; isso levou ao mapa atribuir a data aproximada de 1574. Ao analisar os elementos internos, o fato de estarem representadas terras de Castela e os diversos topônimos na correspondente língua, levou a considerar sua feitura na época filipina, sendo posterior, portanto, a 1580. Com mais algumas razões, chegou-se a 1586. Uma parcela razoável da argumentação apoia-se nos nomes dos donatários, e aí começam as dificuldades. Por exemplo, João de Barros faleceu em 1570 e, assim, o mapa deveria ser anterior a essa data; por outro lado, como se mostrará, o nome de Francisco Barreto só poderia constar nesse mapa a partir de 1584, e, portanto, o mapa deveria ser posterior a essa data: está estabelecido o conflito. Outra incongruência está nas capitanias de Santo Amaro e Itamaracá, sempre pertencentes ao mesmo donatário - no mapa, a primeira pertence a Lopo de Sousa e a segunda, a Francisco Barreto, que nem sequer era donatário, mas casado com a donatária.

Como solucionar esses conflitos? Chega-se a um melhor entendimento tendo em conta que nos mapas em geral uma é a data do levantamento dos 
dados e outra, a da sua confecção e/ou publicação. Inclusive nos dias de hoje, mapas de grandes extensões levantados por aerofotogrametria só são disponibilizados anos depois. Também cabe pensar em acréscimos tardios do mesmo autor ou de outro, sem que houvesse uma atualização dos dados anteriores. No caso, para atualizar, poderia se colocar na primeira capitania ao norte o nome do herdeiro de João de Barros. Assim, como está, o mapa pode ser considerado como da data mais tardia (1584), com informações antigas ou ultrapassadas (1570). Entre as informações e a conclusão do mapa medeiam, portanto, alguns anos.

Por tudo o que foi visto, para esse e para outros casos, há motivos para não considerar um mapa como um retrato fiel, uma fotografia da realidade em determinada data. É ou pode ser um documento histórico, como tantos outros, textos, objetos arqueológicos, e como eles, sujeito a críticas e correções.

Comparação com as demais cartas do Roteiro

Como se disse, o atlas é um anexo ao Roteiro de todos os sinais, e pode ser ilustrativo compará-lo com as demais peças cartográficas que aparecem mescladas com o texto.

Nessa comparação vale destacar que os mapas ou cartas náuticas são um bom complemento a qualquer Roteiro - gênero literário português do Quinhentos, dos quais são exemplares também as obras de Gândavo e de Sousa ${ }^{21}$, contemporâneas ao atlas. Descrevem terras ao longo da costa de norte a sul, fornecendo latitudes, distâncias em léguas entre locais consecutivos, profundidade do mar em braças, bem como outros sinais descritivos da costa e da paisagem: arvoredos, campinas, cabos, serras, correntes e ventos sazonais, baixios, ilhas e abundante toponímia. Escrito em primeira pessoa, descreve para si mesmo o que vai encontrar mais adiante, sendo um diário e um guia de navegação e pilołagem.

Os mapas inclusos no Roteiro são plantas de cidades e de regiões maiores: Vila d'Olinda, Bahia de todo los santos e da cidade do Salvador, Rio de Janeiro, Sam Vicente, Cabo de Santo Agostinho, Os llheos, Villa de S. Jorge, Capitania de Porto Seguro, Região da Villa do Spirito Santo, C. Frio, Amgra dos Reys, Rio da Prata, estreito de Magalhães.

Daí já decorre uma primeira comparação: explicitamente, só figuram no atlas a Villa dolinda e a cidade de S. Sebast $t^{\circ}$, omitindo-se as demais presentes no Roteiro, nomeadamente Salvador, São Vicente, Santos, Itanhaém, São Jorge, Espírito Santo.

Para efeito de comparação, apresenta-se (Figura 4) uma dessas plantas. De grande escala, essas plantas são ainda mais bonitas que o atlas, por suas aguadas e cores mais suaves, pelo maior capricho na letra, embora sejam do mesmo estilo, pela inserção de ilustrações, como as das vilas, fazendas, fortes e fortalezas. 
22. Ver Francisco Adolfo Varnhagen (1956, v. I e II) e Carlos Malheiro Dias (1921, III).

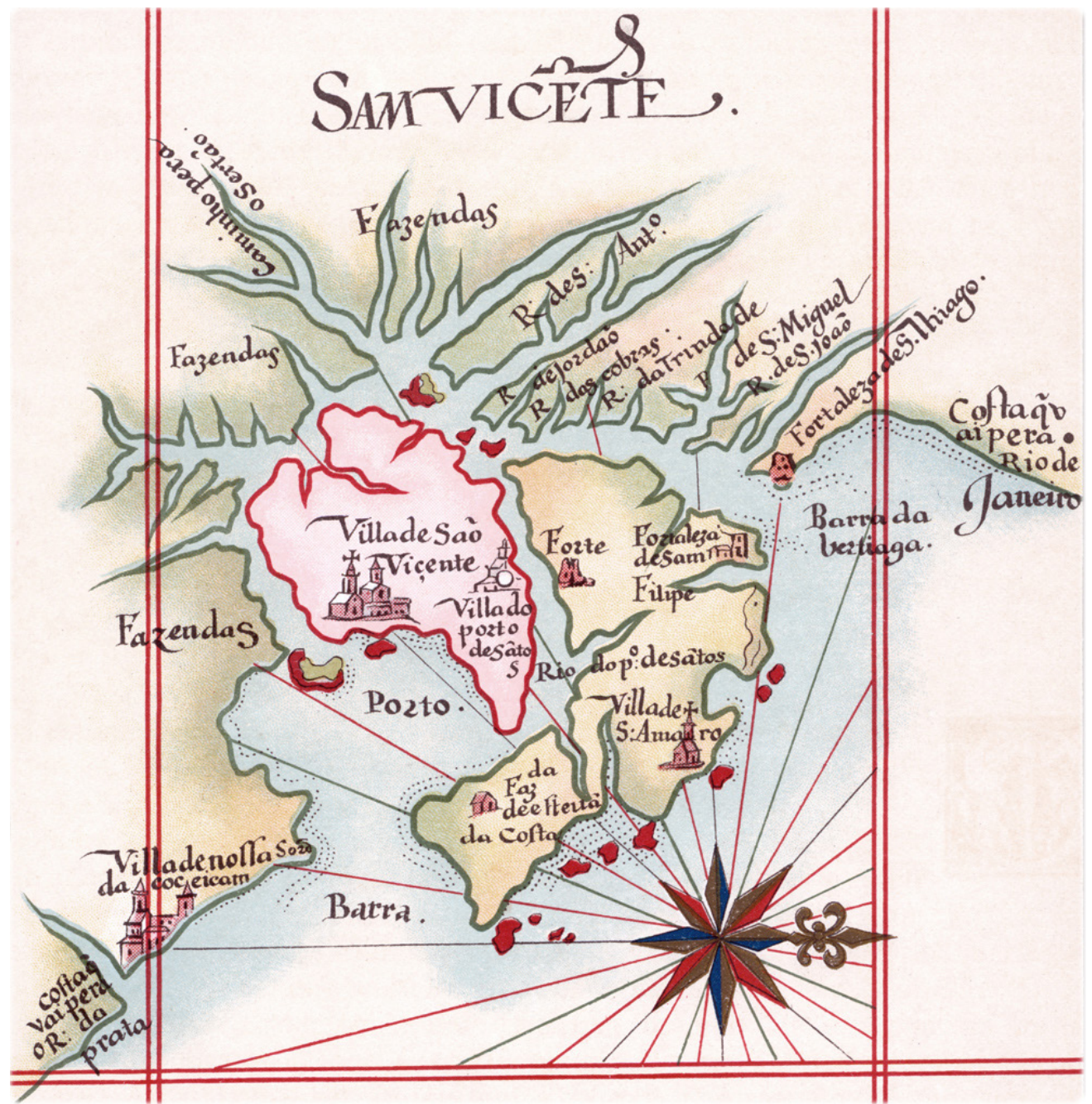

Figura 4 - Planta de Sam Vicente, constante do Roteiro da Biblioteca da Ajuda

Análise das transformações cartográficas nas capitanias

A partir deste item, território a território, são resumidas as vicissitudes pelas quais passaram as capitanias, para avaliar as modificações que as conduziram da situação inicial, resumida na (Figura 5), até à que se vê no mapa de Luís Teixeira (Figura 1)22. $\bigcirc$ período de análise é de 50 anos (1536-1586) e, em geral, as informações estão dispersas ao longo dessas e de outras obras. $\bigcirc$ foco é determinar o donatário que estava na posse da capitania na data do mapa, num processo interativo, que procura determinar também com mais precisão a data do Atlas. Como se verá, surgem incompatibilidades.

Nesse percurso serão resumidas as principais efemérides de cada donatário e capitania, enfatizando aquelas que podem ter consequência e expressão cartográfica, como a morte do titular e transpasse ao herdeiro, a 


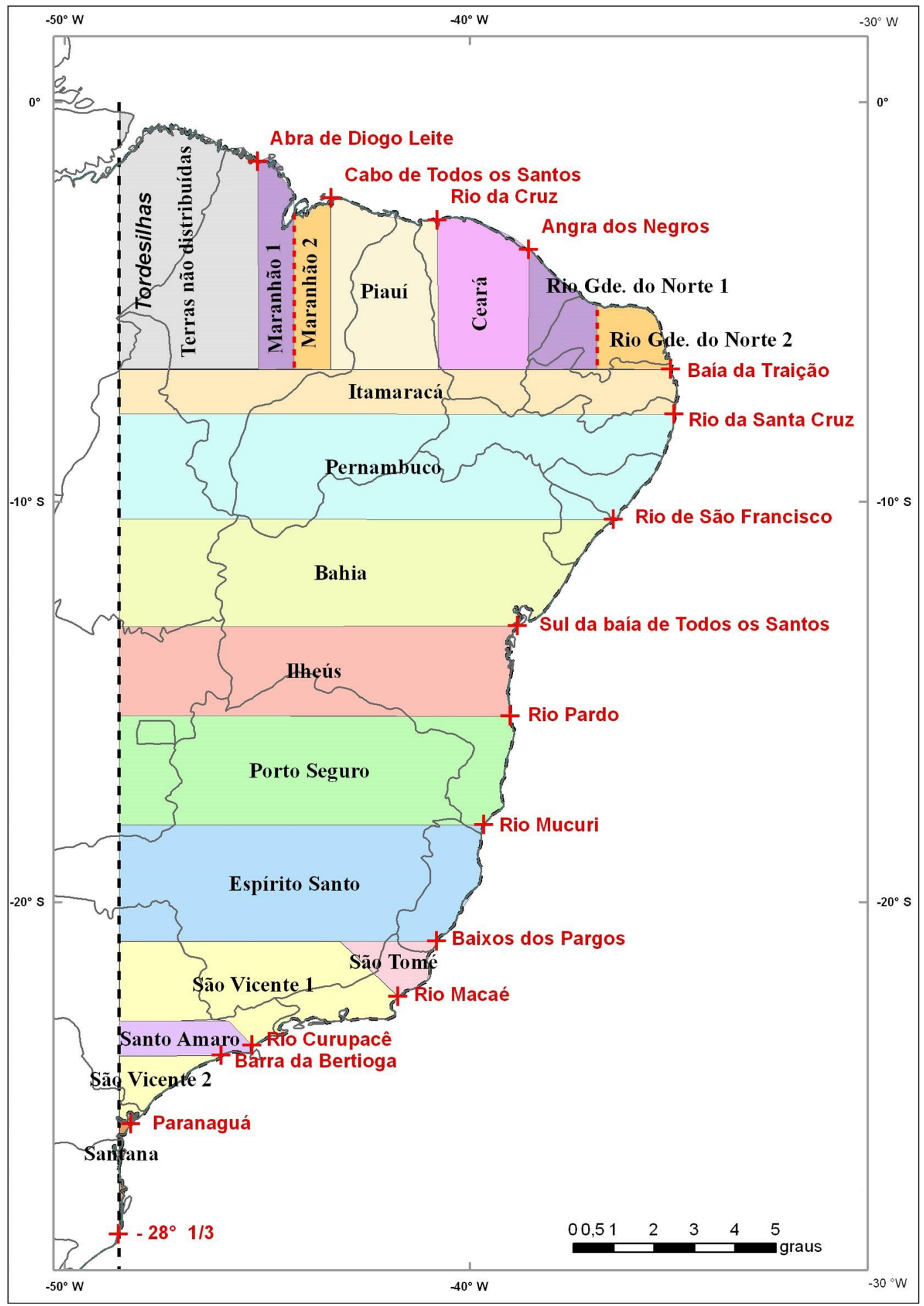

Figura 5 - Capitanias hereditárias no momento de sua criação (1534-1536). Fonte: Jorge Pimentel Cintra (2013). 
23. Cf. Bartolomeu Velho (1561).

24. Ver João de Barros \& Diogo do Couto (1777), Décadas da Ásia confusão de um procurador ou capitão-mor com o donatário, a venda da capitania ou ocupação de fato por parte da coroa.

A primeira constatação, olhando o novo mapa, é de que não existem mais as terras não distribuídas da divisão primitiva. Nesta, D. João III distribuiu todas as terras da Abra de Diogo Leite até o paralelo $28^{\circ} 1 / 3$, locais por onde passaria a linha de Tordesilhas. Posteriormente, a linha de Tordesilhas foi deslocada para oeste, em todos os mapas e por determinação régia, a fim de que os extremos fossem a foz do Amazonas e a do Prata. Restariam, portanto, nessa nova situação, terras não distribuídas ao norte e ao sul. O mapa de Bartolomeu Velho apresenta essas terras ao sul, grafando a expressão "Del Rey Nosso Senhor"; subentende-se que se trata de terras e não capitanias, pois não havia povoamento algum. Mas ao norte, esse cartógrafo estende as terras de Aires da Cunha (o lote mais a oeste de todos) até a linha de Tordesilhas. Era uma falta de informação dos verdadeiros limites desse lote.

Em função da dificuldade de ler, mesmo no original deteriorado desse mapa, transcreve-se a seguir o nome dos donatários, de norte a sul, atualizando a grafia e estendendo as abreviações: Capitania de Aires da Cunha, de João de Barros, de Fernão Álvares de Andrade, de Antonio Cardoso, de Aires da Cunha, de João de Barros, de Pero Lopes de Sousa, de Duarte da Costa, del Rei nosso Senhor, de Lucas Giraldes, de Pero do Campo, de Vasco Fernandes, de Pero de Góis, de Pero Lopes de Sousa, de Martim Afonso de Sousa, del Rei nosso Senhor ${ }^{23}$.

João de Barros (capitanias do norte)

A nova unidade política no atlas ocupa toda a região norte, em que se situavam as capitanias do Maranhão, Piauí, Ceará, Rio Grande do Norte, agora agrupadas em uma só e pertencente ao cronista da Ásia portuguesa, João de Barros, e incluindo também as terras não distribuídas, já que o limite desse território chega à Linha de Tordesilhas.

Essa divisão geográfica corresponderia a João de Barros ter comprado as demais capitanias. Seria uma hipótese a considerar, mas não se conhece documento algum trespassando as capitanias de Aires da Cunha, Fernão Álvares de Andrade e Antonio Cardoso de Barros a João de Barros. Pode-se, de qualquer forma, perguntar pelos motivos que levariam a essa consideração.

Aires da Cunha, valente nauta que se distinguira como capitão-mor do mar em Málaca, como o qualificam as crônicas, chefiou a expedição em sociedade, que representava também os esforços de Fernão Álvares de Andrade e João de Barros para colonizar os territórios dos três. Como se sabe, chegando às águas do Maranhão em março de 1536, um naufrágio ceifou a vida de muitos homens, entre eles o próprio Aires da Cunha. Além dos investimentos perdidos, ficaram muitas dívidas, inclusive para com a coroa. $\bigcirc$ autor das Décadas ${ }^{24}$, com pena da viúva e dos órfãos, pagou todas as dívidas do capitão-mor e de outros. Mas não há documento de que a viúva ou algum herdeiro tivesse alienado a 
capitania - coisa que exigiria a autorização régia, como se constata no transpasse das capitanias de llhéus e de Porto Seguro ${ }^{25}$. A coroa teria também interesse nessa compra e, de fato, é ela quem está na posse de todo esse território da região norte, quando se empreende a conquista que vai de Sergipe a Belém, de 1590 a 1616.

Fernão Álvares de Andrade foi importante conselheiro do rei e tesoureiromor do reino; enquanto viveu foi ardente defensor de providências a favor do Brasil. Não há registro de outra tentativa de colonizar sua capitania. Talvez parte de suas dívidas tenham sido perdoadas pelo rei, como aconteceu a João de Barros, e a capitania entrou nas negociações. Dias informa que faleceu em 1552 e está enterrado no museu do Carmo, em Lisboa ${ }^{26}$. Assim, o mapa de Bartolomeu Velho (1561) é anacrônico ao consigná-lo em seu mapa.

Com relação a Antonio Cardoso de Barros, cavaleiro fidalgo, há indícios fortes de que suas terras reverteram para a coroa, por ocasião da implantação do Governo geral (1549). Veio ao Brasil com Tomé de Sousa, nomeado para o cargo de provedor-mor da Fazenda, ofício rendoso que the consumia todo o tempo, não sendo, pois, compatível com a instalação de uma vila, sua fixação em residência e a tentativa de cultivar suas terras. Varnhagen tem "por mais provável (...) que, como indenização desses esforços perdidos, é que veio a acompanhar depois a Tomé de Sousa [como provedor-mor]"27. A venda das terras se vê confirmada por um documento de 21 de junho de 1549, em que ele passa um traslado de um foral de sua capitania,

que tem nestas partes, porque manda a Rodrigo Argolo, provedor nesta capitania na cidade do Salvador, para pôr em arrecadação todos os direitos ou pensões que pertençam ao capitão [ele mesmo] para el-rei nosso senhor, bem assim tudo o que pertence ao dito senhor [ele mesmo] por bem do dito foral e que registrassem no Livro de Registros dos forais da alfândega.

Embora devorado pelos índios junto com o bispo Sardinha, em 16 de junho de 1556, continua a figurar anacronicamente no mapa de Bartolomeu Velho, de 1561 .

Com relação ao próprio João de Barros e seus herdeiros (Jerônimo e João), depreende-se da documentação ${ }^{28}$ que, depois de grande desânimo após o naufrágio dos tempos iniciais com Aires da Cunha (1536), enviou seus dois filhos, uns 20 anos mais tarde (1556), a fazerem nova tentativa, na qual estiveram mais de 5 anos nas costas do Brasil ${ }^{29}$. Esse novo empreendimento coaduna-se bem com o fato de haver na Carta de mineração ${ }^{30}$ uma cláusula dizendo que os três sócios Voão de Barros, Aires da Cunha e Fernão Álvares de Andrade), transcorridos 20 anos, deveriam informar ao rei a divisão de terras que tivessem feito. Chegando ao limite do prazo e com o risco de perder por inação as terras e o investimento feito, os filhos empreenderam nova viagem colonizadora que, se não deu resultados práticos, talvez tenha sido o ponto de partida das negociações com a coroa, culminando com o transpasse das terras à coroa, em acordo feito com o filho do donatário, Jerônimo de Barros ${ }^{31}$, após a morte do pai e já no governo de Felipe II, portanto, depois de 1580.
25. Contra esse transpasse há o mapa de Bartolomeu Velho (1561), no qual ainda consta Aires da Cunha como donatário, coisa que não é estritamente correta, pois, como já era falecido, deveria constar o nome de um seu herdeiro. O mapa também poderia não estar com essa informação atualizada.

26. Ver Carlos Malheiro Dias (1921).

27. Cf. Francisco Adolfo Varnhagen (1956, v. I, p. 198).

28. Um alvará de 05 de março de 1561 faz alusão à primeira e segunda tentativas; desta última diz "e haverá cinco anos [portanto por volta de 1556] que mandou outra em que foram dois filhos seus a povoar a dita terra". Cf. António Baião (1918, p. 202 e ss.).

29. Ver Carlos Malheiro Dias (1921, p. 209-210).

30. Carta real de doação de minérios, transcrita por António Baião (1932, p. XXVIII a XXXIX).

31. Jerônimo de Barros, filho mais velho e herdeiro, dirige uma petição sem data para ir povoar sua capitania, em terceira tentativa, que não teria acontecido. $\mathrm{O}$ fato derradeiro é que este monarca lhe concedeu uma indenização em função dos gastos realizados e ficou com as terras. Ver Francisco Adolfo Varnhagen (v. I, p. 196) e a correspondente nota de Rodolfo Garcia, em que se citam os já mencionados documentos publicados por António Baião. 
32. Ver Pedro Taques (1772, p. 83). Carlos Malheiro Dias (1921, p. 234) assinala o ano de 1547 para sua morte.

33. Pelas cartas de doação, as mulheres herdavam o território, contrariando a chamada Lei Mental. Fato que se verifica não só nesse caso, mas também com a Condessa de Vimieiro, D. Mariana de Sousa Guerra, que foi donatária de São Vicente. Para essa família, a carta de doação obrigava à manutenção do sobrenome Sousa, sob pena da perda das terras. Assim, a ausência do sobrenome Sousa, para quem conhecesse as cláusulas de doação, seria um indício de que Francisco Barreto não poderia ser herdeiro.

34. Procuração transcrita em Pedro Taques (1772, p. 8788).

35. Ver Francisco Adolfo Varnhagen (1956, v. II, p. 17, nota 27), Cartas, informações e fragmentos bistóricos, citado por Capistrano de Abreu.
Do ponto de vista cartográfico, em 1586, admitindo ser essa a data do mapa, as terras já não pertenciam a João de Barros, mas a seu primogênito e herdeiro, Jerônimo de Barros, desde a morte do pai em 1570. O mapa de Luís Teixeira deveria consignar o nome do herdeiro.

\section{Francisco Barreto (ltamaracá)}

Como já se salientou, a posição da linha divisória dessa capitania, ao norte, está equivocada, resultando em uma largura e extensão de terra muito maior do que a real. $\bigcirc$ limite não passa pela Baía da Traição, como deveria. $\bigcirc$ cartógrafo, sem dúvida, não teve acesso à carta de doação de Pero Lopes de Sousa, em que os limites aparecem bem claros e definidos. Também não atentou ao fato de o mesmo donatário de Itamaracá possuir terras ao sul: São Tomé e Santana. O donatário das três porções é o mesmo, o que, afora outras considerações, não ocorre nesse mapa. O Mapa de Bartolomeu Velho, na data de sua feitura (1561), apresenta Pero Lopes de Sousa, que morrera em torno de 1540, como donatário de Itamaracá e Santo Amaro. Informação defasada, mas o donatário é o mesmo em duas porções; não leva em consideração o último lote desse donatário (Terras de Santana).

Para esclarecer esse ponto faz-se necessário seguir brevemente a trajetória dos herdeiros do primeiro donatário, Pero Lopes de Sousa. Este faleceu em 1539, segundo Jaboatão, sendo seguro que já o estava em 1542, pois D. Isabel de Gamboa, sua mulher, passa uma procuração como tutora do herdeiro Pedro Lopes (2. ${ }^{\circ}$ donatário), que morreu com pouca idade, por volta de $1546^{32}$. Passa a capitania ao 2. ${ }^{\circ}$ filho, Martim Afonso (3. donatário e homônimo do tio), e sendo menor de idade, teve também sua mãe como tutora. Falecendo este, passa a capitania à sua irmã Jerônima de Albuquerque e $\operatorname{Sousa}^{33}$ (4. ${ }^{a}$ donatária e 3. ${ }^{\text {a }}$ filha de Pero Lopes de Sousa), casada com Antonio de Lima. Em 1577, ainda vivia e era viúva. Teve uma única filha, D. Isabel de Lima de Sousa e Miranda (5. ${ }^{\text {a }}$ donatária, neta de Pero Lopes de Sousa). Esta casou em primeiras núpcias com André de Albuquerque. Em 1577, os três, Jerônima, Isabel e André, na vila de Setúbal, assinam uma procuração a favor de Lourenço da Veiga, para tratar dos interesses da capitania de Santo Amaro ${ }^{34}$. Provavelmente a assinatura conjunta deve-se ao excesso de zelo. Se Jerônima vivia e não estava impedida, a ela isoladamente competia assinar, sem o concurso de sua filha, nem de seu genro. A assinatura dos três talvez fosse para não deixar dúvida, incluindo para aqueles que, sem conhecerem as cartas de doação, consideravam que é ao homem a quem compete herdar e governar. Em segundas núpcias, Isabel casou-se com Francisco Barreto de Lima, que aparece no mapa de Luís Teixeira, sem o último sobrenome. O cartógrafo tomou o consorte por donatário e consignou seu nome no mapa. Então, do ponto de vista da datação, a confusão seria possível a partir da data do casamento, que não se conhece com certeza. Mas Anchieta ${ }^{35}$, tomando também ○ 1. ${ }^{\circ}$ marido como governante, afirma que André de Albuquerque era o donatário 
em 1584 e, portanto, estava vivo nessa data ${ }^{36}$. Assim, Francisco Barreto só se teria casado a partir desse ano e nessa situação poderia ser considerado como donatário, ainda que erroneamente. Essa é a informação mais tardia desse atlas e justifica a data de 1584. Frei Gaspar ${ }^{37}$ cita uns autos, escritos em 1597, em que se menciona Francisco Barreto de Lima como donatário da capitania de Santo Amaro e, portanto, também de Itamaracá; Isabel viveria nessa data, para que o marido pudesse ser considerado donatário. Ela morreu sem filhos, e assim as terras que haviam pertencido a Pero Lopes de Sousa ficaram sem herdeiro descendente direto, testando essa senhora a favor de seu primo, Lopo de Sousa, neto de Martim Afonso de Sousa, donatário de São Vicente, reunindo, assim, em sua pessoa, todas as terras dos dois irmãos. Este exerceu atos de jurisdição sobre todos os territórios, pelo menos a partir de $1602^{38}$. De maneira que se pode situar a morte de Isabel e o transpasse da capitania entre os anos de 1597 e 1602.

Jorge de Albuquerque Coelho (Pernambuco)

Duarte Coelho Pereira, primeiro donatário, faleceu em 1554. Sucedeuthe seu filho Duarte Coelho de Albuquerque (2. ${ }^{\circ}$ donatário), ainda menor de idade, pelo que a viúva, D. Brites (Beatriz) de Albuquerque, governou e administrou, como tutora de seu filho. Este seu primeiro filho e o segundo, Jorge de Albuquerque Coelho, acompanharam D. Sebastião na batalha de Alcácer Quebir locorrida em 04 de agosto 1578). O primogênito, solteiro, ferido na batalha, morreu em 1579, como consequência dos ferimentos. $\bigcirc$ segundo, Jorge de Albuquerque Coelho, que havia cedido seu cavalo ao rei D. Sebastião durante a batalha, foi nela ferido, feito prisioneiro e resgatado. Foi também herói de um naufrágio que sofrera. Tornouse 0 3. ${ }^{\circ}$ donatário da Capitania de Pernambuco, e é quem figura no mapa. A notícia da morte do irmão mais velho chegou a Lisboa em 1580, e ele recebeu a confirmação do rei como donatário em 15 de maio de 1582, coisa que é compatível com a data de 1584 para o Atlas. Foi sucedido por seu filho Duarte de Albuquerque Coelho, com carta real de confirmação de 1603.

De sua majestade

Ao chegar ao que seria a capitania da Bahia, verifica-se uma descontinuidade semântica. Não se grafa "capitania de", mas simplesmente, e em letras maiúsculas: "De sua Majestade". Quer-nos parecer que se trata de terras de sua majestade e não de uma capitania em sentido estrito, como as demais. Para isso, vale "abrir um parêntese" para examinar o sentido dessa expressão.

Capitania, um termo polissêmico

Para não dizer que se trata de um termo equívoco, pode-se classificá-lo como análogo. Emprega-se em sentidos diversos com algo em comum, assim como
36. Jaime Cortesão (1944, p 58) afirma que esse André de Albuquerque seria sobrinho neto do grande Afonso de Albuquerque, e teria falecido na batalha de Alcácer Quibir. Informação incompatível com a de Anchieta. Capistrano de Abreu e Antonio de Alcântara Machado invertem a ordem dos matrimônios de Isabel de Lima: esta teria se casado primeiro com Francisco Barreto e depois com André Albuquerque; o que causou muita confusão em assunto já de per si intrincado.

37. Ver Frei Gaspar (1975, p 180).

38. É o que se deduz de um documento resumido por Pedro Taques (1772, p. 8990). 
39. O texto diz literalmente: "A esta cidade do Salvador deve sua alteza de prover um capitão honrado e abastado, porque a qualidade dela o demanda assim e o Governador geral não deve ter lugar certo, senão residir onde lhe parecer que há mais necessidade dele". Carta-relatório de Tomé de Sousa, de $1^{\circ}$ de junho de 1553. Cf. Vicente Tapajós (1966, v. II), História Administrativa do Brasil. Já antes disso, a 15 de julho de 1551, enviava missiva ao rei, na qual sugeria enviar ao Salvador "um alcaide-mor que pudesse pela mesma cidade responder, durante a ausência do Governador geral". Cf. Francisco Adolfo Varnhagen, 1956 (v. I, p. 260).

40. Fazendo lembrar os Morgados. seu correlato, capitão. Assim, as naus da carreira das Índias ou as expedições exploratórias da costa brasileira possuíam um capitão-mor, que ia na nau capitânia (observe-se o acento, para diferenciar de capitania territorial); e cada nau possuía um capitão subalterno, e numa delas ia o vice-comandante, ou soto-capitão. Assim ocorre, por exemplo, com Vasco da Gama, Pedro Álvares Cabral e com Martim Afonso de Sousa na expedição exploratória de 153 1-1533. Também é chamado Capitão I, sendo esse I interpretado como Primeiro (algarismo romano) ou mesmo como Irmão, pois o diário que se conserva é de Pero Lopes de Sousa.

As expedições que vinham guardar a costa, como as de Pero Capico, Gaspar de Lemos e Cristóvão Jaques, seguem a mesma regra. Nessas havia de certo uma jurisdição territorial, no caso a cosła brasileira, sendo missão vigiar, expulsar corsários, mas não cultivar a pesca e desenvolver o mar; prende-se mais fortemente a uma missão. E assim a jurisdição poderia ser classificada de pessoal: governa homens, uma armada, para uma missão concreta. E da mesma maneira, há capitães da conquista do sertão, da guerra contra os bárbaros e mesmo de viagens. Para cada missão há um regimento: Tomé de Sousa recebeu um regimento para a viagem até o Brasil e outro para governar o país. Ele mesmo terá de estabelecer um regimento específico para Pero de Góis, nomeado capitão-mor da costa brasílica.

Por outro lado, o próprio Tomé de Sousa tinha consciência de que sua missão de governador-geral não exigia um território específico de seu governo: supunha uma missão e o governo de todas as capitanias, mas não o de uma capitania determinada, que o igualasse aos donatários. Isso é afirmado por ele claramente em carta a D. João III, dizendo que deveria ser nomeado um administrador da cidade do Salvador, coisa que só consome tempo ao governador-geral, e quanto a este, deveria residir em local variável, onde fosse mais oportuno em cada momento ${ }^{39}$.

Por outro lado, o termo capitão-mor logo deixou de ser usado para os donatários. Muitos deles vieram para governar pessoalmente sua capitania, mas pouco a pouco os sucessores não mais se transladaram para cá e nomearam seus loco-tenentes, passando procuração e transmitindo-the amplos poderes. Estes, então, passaram a chamar-se capitães-mores, sem serem donatários. A função destes últimos passou a ser, ao final das contas, a daqueles que recebiam os dízimos de certas mercadorias, conforme previa o foral de sua capitania, e possuíam um título que thes dava certa nobreza ${ }^{40}$, e esporadicamente criavam vilas ou exerciam algum ato excepcional de jurisdição por si próprio; mas não estavam no dia a dia e, por vezes, muito distanciados da realidade e problemas locais.

Capitania de uma cidade ou de um território?

Embora os documentos falem da Capitania da Bahia, parece-nos que não houve capitania real, em sentido próprio, nos primeiros anos; coisa que passamos a justificar na sequência.

Em primeiro lugar porque uma capitania real não pode ter um estatuto jurídico semelhante ao das hereditárias: não há uma carta de doação do rei para 
si mesmo; não existem poderes, no cível e no crime, delegados para uma dinastia familiar; não existe transmissão de direitos nem de governo: o rei nomeia quem quer, pelo tempo que quiser; não há dízimas ou impostos para um intermediário e assim por diante: nenhum elemento que caracteriza as capitanias hereditárias: a semelhança está somente na existência de um território, no caso da Bahia, confinado pelos mesmos confrontantes do antigo donatário. Mas esse território é simplesmente terra do rei, como o são também as terras não distribuídas ao norte ou os territórios ao sul, sem núcleo urbano, povoação ou qualquer estrutura jurisdicional, de fato ou de direito.

Assim, nos primeiros momentos, não se fala de uma capitania que ocupasse o território da Capitania de Francisco Pereira Coutinho. $\bigcirc$ regimento de Tomé de Sousa menciona somente a jurisdição sobre uma fortaleza e povoação, nem sequer fala de uma cidade ${ }^{41}$ - termo que surgiu no ano seguinte. Explicitamente esse regimento estabelece um perímetro urbano (o rocio de uma légua e meia) e um termo (de seis léguas) que representa o confim do território, da mesma forma que ocorria com as vilas. Se houvesse razões para ocupar ou explorar um território fora desses limites, o governador deveria fazer uma consulta para que a coroa estudasse o que era melhor fazer. Como se viu, Tomé de Sousa advogava a tese de um governador-geral sem território.

Lendo atentamente os documentos, vê-se que, além de governador-geral, Tomé de Sousa foi capitão e governador de um território sim, mas constituído por uma cidade, a do Salvador, e seu entorno, a Bahia de Todos os Santos. Não do território da Capitania de Francisco Pereira Coutinho.

Dias transcreve diversos documentos que confirmam essa tese. Por exemplo, Duarte da Costa, no documento de sua nomeação pelo rei, em 1. ${ }^{\circ}$ de março de 1553, lê-se: "que ajam ao dito Dom Duarte da Costa por capitam da dita cidade do Salvador e governador-geral das outras capitanias e terras do Brasil"42. Da nossa parte, encontramos também documentos na Torre do Tombo a favor dessa posição: o primeiro é uma carta de Tomé de Sousa a D. João III, de 18 de julho de 1551, com o título manuscrito Carta do Governador da Cidade do Salvador no Brasil... ${ }^{43}$. Um segundo é também um documento real sobre os ordenados de Mém de Sá, "que ora encontro por capitão da cidade do Salvador da Bahia de todos os santos e por governador geral das outras capitanias e terras do Brasil..." 44 . Ainda outro, também do cartório dos jesuítas, reconhece isso no próprio título: "Traslado do foral da capitania da cidade de Salvador da Baía"45. Mais um nesse sentido é uma transcrição, por parte de Frei Gaspar, de um documento de D. Sebastião, de 02 de outubro de 1564, que se refere a "Mém de Sá, do meu concelho, Capitão da minha cidade do Salvador e governador geral por mim em todas as Capitanias, terra da Costa do Brasil..." 46.

Em algum outro documento relativo à cidade de Salvador acrescenta-se: "na Bahia de Todos os Santos" ou mesmo se escreve "a Capitania da baía de todos os santos", mas creio que se refere ao acidente geográfico, onde se localiza Salvador, e não às terras que haviam pertencido a Francisco Pereira Coutinho.
41. O regimento de Tomé de Souza, de 17 de dezembro de 1548, datado em Almeirim, diz textualmente: "Ordenei ora mandar ... fazer uma fortaleza e povoação grande e forte ... para daí se dar favor e ajuda às outras povoações". Cf. Arquivo Histórico Ultramarino (códice 112, fl. 1). A palavra fortaleza repete-se 9 vezes nos 7 primeiros artigos desse regimento. Disponível em: $<$ http://www.historia-brasil. c o m / c o 1 o n i a / constituicao-1548.htm>.

42. Cf. Carlos Malheiro Dias (1921, p. 366).

43. Cf. ARQUIVO NACIONAL DA TORRE DO TOMBO (cód. ref. PT-TT-CC-1-86-96). Disponível em: <http:// digitarq.arquivos.pt/ viewer?id=3778561 $>$. Ainda que quem classificou, tardiamente, esse documento colocou o título Governador da Bahia. Não se menciona, mas trata-se de Tomé de Sousa.

44. Cf. ARQUIVO NACIONAL DA TORRE DO TOMBO (cód. ref. PT/TT/AJCJ/ CJ019/00025, transcrição paleográfica nossa).

45. Cf. Ibid. (cód. ref. PT/TT/ AJCJ/CJ018/00010).

46. Esse texto de Frei Gaspar, citando D. Sebastião, pode ser encontrado também na Torre do Tombo, que detém parte de alguns manuscritos que serviram de base para suas Memórias, junto com papeis sobre a mineração em São Paulo, Goiás, Cuiabá, Mato Grosso e a História da expulsão e reintegração dos jesuítas de seu Colégio de São Paulo, escrita por Pedro Taques, em 1770. Todos reunidos sob o título Fundação da capitania de São Vicente e acções de Martim Afonso de Sousa no Brasil e outros papeis. Cf. ARQUIVO NACIONAL DA TORRE DO TOMBO (cód. ref. PT-TT-MSBR-48). 
47. Cf. Rocha Pita (1950, p. 59).

48. Cf. Carlos Dias (1921, p. 327, 335).

49. Ver Carlos Malheiro Dias (1921).

50. A história de cada donatário, resumida no presente trabalho, é uma prova disso. A chamada Conquista do Norte aos Bárbaros é também prova eloquente, e as capitanias do sul, São Vicente incluída, só foi avante por uma paz conseguida por Nóbrega e Anchieta. A vila de São Paulo esteve à beira da destruição em 1562.

\section{A capitania da Bahia: criação e limites}

Costuma-se afirmar que o rei comprou a Capitania da Bahia e a seguir implantou nela a cidade do Salvador. Rocha Pitta afirma que ela foi tomada ao indicar que "Por morte do donatário tomou El Rey esta Província"47. Dias referindose a "Manuel Pereira Coutinho, que teve a capitania, que el Rei lhe tornou a tirar", acrescenta que "el rei lançou mão da capitania, satisfez o herdeiro do defunto donatário e mandou fundar uma nova cidade na Bahia"48. Essas afirmações são simplificações do que ocorreu. Para entender o que aconteceu, é preciso seguir os acontecimentos $^{49}$.

Francisco Pereira Coutinho iniciou a colonização em 1536, fez doações de sesmarias, fundou aquela que seria chamada vila do Pereira, em alusão ao seu sobrenome. Após ataques dos índios, debandou junto com os colonos e refugiou-se na vizinha capitania de Porto Seguro. Quando retornou à sua vila, naufragou, e tendo sobrevivido, foi devorado pelos índios, isso em 1546. De fato, um dos maiores problemas das capitanias foi a resistência e os ataques indígenas ${ }^{50}$. Somando-se a isso a aliança dos índios com os franceses, via-se de alguma forma ameaçada a soberania e o domínio do território. Os sucessos na Bahia foram a gota d'água para a intervenção da coroa: o rei cria e implanta o governo-geral pouco tempo depois (1549).

O rei, em função dessas graves circunstâncias, resolve criar uma fortaleza que fosse inexpugnável, como as da Índia e da África (recorde-se São Jorge da Mina). Lendo o regimento de Tomé de Sousa, salta à vista a preocupação com a segurança e a menção à fortaleza, a se estabelecer, cercar, murar e defender. A povoação anexa é uma consequência: não há fortaleza sem homens, nem homens dedicados de forma permanente sem suas famílias, e sem um pequeno território em que se possa cultivar e criar gado. Expandir-se para fora desse termo seria arriscar a segurança. Se algum engenho isolado fosse construído, que tivesse sua torre e fortaleza.

Então, se o rei ocupou terreno alheio, foi por motivo de força maior: a segurança e o domínio do território. Assegurado isso, como reza seu regimento, Tomé de Sousa devia providenciar socorro às capitanias que o necessitassem. Mas a terra não foi comprada nesse instante. Isso só veio a ocorrer em 1576, 40 anos depois da doação e mais de 25 anos depois da implantação do novo sistema. Como se apontou ao comentar a cartela, Manuel Coutinho, filho do donatário, cedeu a capitania à coroa em troca de uma tensa anual hereditária, como compensação.

A prática de doação de terras em sesmaria, poder conferido a Tomé de Sousa, foi mesmo restrita a esse termo da vila. E fora desse termo não houve a criação de qualquer povoação; mais tarde, São Cristóvão do rio Sergipe do rei será criada em território real, nas terras da coroa que antes pertenceram a Francisco Pereira Coutinho; e também com um termo de pequenas dimensões iniciais: as 6 léguas em quadra. 
Em continuidade a essa delimitação, poderia se dizer que Tomé de Sousa governava uma capitania-cidade, com 6 léguas de termo. E pode-se pensar em desenhar esse território dentro da região que pertencera ao donatário. É o que se faz na (Figura 6).

Nessa figura desenhou-se um círculo de 6 léguas, pois era isto o que significava a expressão 6 léguas em quadra - medir léguas em todas as direções e caminhos. Por esse desenho verifica-se um conflito: Ithéus; capitania que começava na ponta do padrão, na margem sul da Baia de Todos os Santos (linha verde penetrando no círculo vermelho). Isso foi advertido por quem redigiu o regimento de Tomé de Sousa, talvez com o apoio de algum cartógrafo, pois nele se especifica: "hei por bem que tenha por termo e limite seis léguas para cada parte, e sendo o caso que por alguma parte não haja as ditas seis léguas, por não haver tanta terra, chegará o dito termo até onde chegarem as terras da dita capitania".

Finalmente, vale assinalar a existência, dentro desse círculo, de duas sesmarias, uma Itaparica e Tamarandiva (junto à primeira ilha), e outra Paraguaçu (ao fundo da baia), que mais tarde (1556 e 1565) ganharam um status jurídico semelhante ao das capitanias, sendo na realidade microterritórios, com características e privilégios hereditários.

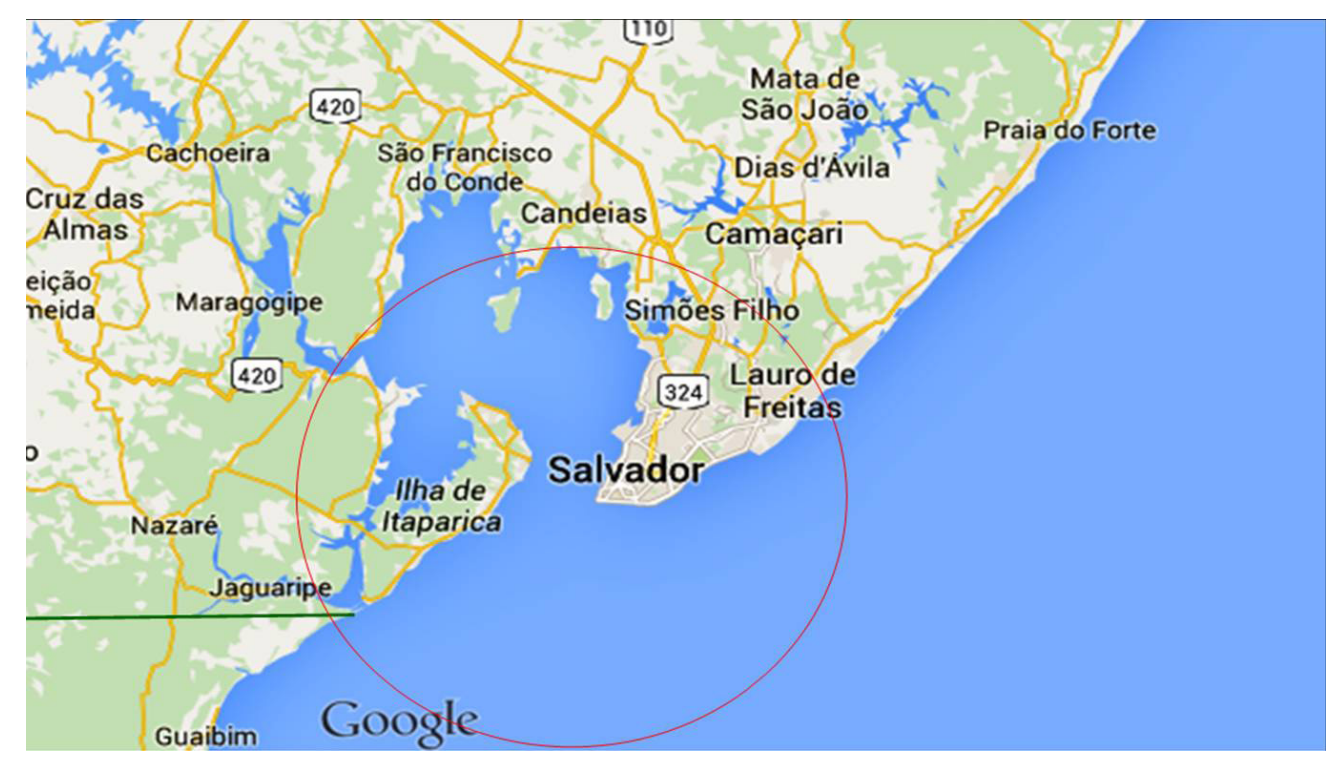

Figura 6 - Capitania cidade do Salvador. Com 6 léguas à volta do centro da cidade. Esquema elaborado pelo autor, a partir da imagem do Google Maps.

Francisco Giraldes (Ilhéus)

Jorge de Figueiredo Correia, $1^{\circ}$ donatário, escrivão da Fazenda real, fundou a vila de São Jorge (seu autônimo) e, de acordo com Sousa ${ }^{51}$, foi o primeiro 
52. Ver Francisco Adolfo Varnhagen $(1956$, v. I, p. 307).

53. Cf. Francisco Adolfo Varnhagen (1956, v. I, p. 188, nota X de Rodolfo Garcia).

54. Ver Francisco Adolfo Varnhagen (1956, v. I, p. 307). Carlos Malheiro Dias (1921, p. 205) afirma que o Duque de Aveiro recebeu confirmação em 1556, baseado em documento da Torre do Tombo: Chancelaria de D. João III (liv. 54, fl. 243 v). a cultivar a cana de açúcar. Teve como filhos Jorge de Figueiredo, primogênito, e Jerônimo de Figueiredo Alarcão. $\bigcirc$ primeiro assumiu por morte do pai em 1551 e cedeu a capitania ao segundo, que a vendeu, em 06 de novembro de 1560, por uma bagatela, ao banqueiro Lucas Giraldes ${ }^{52}$. Este empenhou-se a fundo no desenvolvimento da capitania, tendo criado 8 engenhos, os quais foram, quase todos, destruídos pelos Aimorés. Seu filho, Francisco Giraldes (5. donatário), que aparece no mapa, herdou a capitania em 13 de dezembro de 1565, com o falecimento do progenitor. Posteriormente, em 9 de março de 1588, estando em Lisboa, foi nomeado governador-geral. Embarcou, mas não chegou ao Brasil, em função de uma viagem acidentada, cujas naus só retornaram a Lisboa no ano seguinte. Faleceu logo depois (1589 ou 1590).

No mapa de Bartolomeu Velho (1561), quem consta é Lucas Giraldes, sendo que esse dado permitiria concluir que esse mapa é posterior a fins de 1565, início da posse de Lucas. Portanto, há um erro na datação clássica.

Duque de Aveiro (Porto Seguro)

Pero do Campo Tourinho, rico proprietário em Viana do Castelo (Minho), vendeu tudo e veio ao Brasil. Por razões que não vêm ao caso, foi denunciado à Inquisição de Lisboa em 13 de setembro de 1543; preso em Porto Seguro em 24 de novembro de 1546 e, após longo e desgastante inquérito, remetido a Lisboa, onde ainda respondia ao processo em 1550. Ao que parece, como Duarte Coelho, tinha muito zelo religioso e o processo repousava sobre falsidades.

Em 18 de novembro de 1554, junto com sua mulher, D. Inês Fernandes Pinta, renunciou a favor de seu filho Fernão, ou Fernando do Campo, "mandando logo meter de posse da capitania". Este faleceu sem herdeiros e foi substituído por sua irmã, Leonor do Campo ${ }^{53}$, confirmada em 30 de maio de 1556. Pouco tempo depois, Leonor vende a capitania ao seu solarengo, o duque de Aveiro (D. João de Alencastre), com autorização do rei, com a cláusula de que, por sua morte, passaria a doação a seu segundo filho, para quem constituía um morgado ${ }^{54}$. A venda foi por preço irrisório.

A fórmula do mapa, duque de Aveiro, permite interpretar que era posse de D. João ou de seu filho, herdeiro também do título.

Vasco Fernandes Coutinho (Espírito Santo)

Distinguiu-se por seus feitos em Goa, Málaca e China. Foi protagonista heroico do episódio em que deteve o elefante que trazia a espada na tromba.

Constituído donatário, vendeu sua quinta em Alenquer, contraiu empréstimos e disse adeus ao Tejo. Invocou o Espírito Santo com vistas à fundação, mas parece que começou a abrigar criminosos. Em 1550 partiu de sua capitania para, junto com Duarte Coelho, senhor de Pernambuco, protestar contra o desprezo de suas doações e privilégios que a criação do Governo geral importava. De fato, 
essa centralização criava conflitos de jurisdição, além de uma maior fiscalização e ingerência por parte da coroa, iniciando o processo de reversão de todas as capitanias à posse real.

Sabe-se que em 1555, pobre, velho, cansado e quase demente, retirouse a Salvador, ficando sob a proteção de Duarte da Costa. Devido a contratempo, fugiu para o meio dos gentios e por eles foi morto, nesse ano.

Sucedeu-lhe seu filho (2. ${ }^{\circ}$ donatário), de igual nome ${ }^{55}$. Mas as coisas não melhoraram, de tal maneira que em 1560 escreveu carta de renúncia à capitania. Os moradores estavam decididos a abandonar a terra e, aproveitando uma passagem de Mém de Sá, foram-se a ele, com as mulheres e filhinhos, pedindo-lhe encarecidamente que a tomasse para a coroa, ao que este reagiu, numa espécie de intervenção provisória, nomeando governador interino. Já em carta enviada ao rei (em 1..$^{\circ}$ de junho de 1558), havia proposto que se tomasse a capitania a Vasco Fernandes, "que este donatário velho, aleijado, e sem meios nem esperanças de a poder restaurar, se prontificava a ceder á Coroa, e lembrava, para proteger as capitanias do Sul, que no Espírito Santo se fundasse outra cidade real, como aquela do Salvador, lembrança que depois modificou preferindo, como Thomé de Souza, o Rio de Janeiro"56. A rainha, ao que parece, aprovou essas medidas ${ }^{57}$

segundo Vasco faleceu em 1561, ficando como governadora sua mulher, D. Luísa Grinalda, que fez a entrega dessa ao terceiro donatário, Francisco de Aguiar Coutinho, parece que em 1584. Tendo como certas essas datas o nome Vasco Fernandes Coutinho não deveria figurar no mapa.

Pero de Góis (São Tomé, Paraíba do Sul ou Campos de Goitacazes)

Veio este donatário na expedição exploradora de Martim Afonso e aqui ficou por indicação deste, talvez como loco-tenente e recebeu duas sesmarias em São Vicente. Agraciado com um quinhão de 30 léguas, empenhou-se seriamente no desenvolvimento dessas terras; tomou consigo seu irmão Luis de Góis e veio tomar posse em 1536. Fundou a Vila da Rainha, trouxe a cana de açúcar de São Vicente e voltou ao reino para buscar capitais em 1542. Na volta deparou-se com a deserção do administrador e dos colonos e, apesar de tudo, recomeçou. Sofreu diversos ataques dos índios, num dos quais perdeu um olho. Foi constrangido a deixar a terra, como consta em carta ao rei de 29 de abril de $1546^{58}$.

É com sua presença na corte que se decide, em 1548, a criação do governo central. É escolhido para o cargo de capitão-mor da costa do Brasil ${ }^{59}$ e embarca com Tomé de Sousa. Cumprindo sua missão, percorre a costa brasileira, combate e prende franceses no Rio de Janeiro, no Cabo Frio; vai ao Espírito Santo, socorre o ouvidor-geral e volta a Salvador (1551), de tal forma que mereceu o elogio de Tomé de Sousa: "Cumpria em tudo seus deveres de boa vontade (...) conhecia [a terra] melhor do que ninguém"60. Em 1553, retorna definitivamente a Portugalol. Por sua morte a capitania passou a seu filho Gil de
55. Isso causou certa confusão a alguns, trocando o pai pelo filho, por exemplo. Ver Carlos Malheiro Dias (1921, p. 202).

56. Cf. Francisco Adolfo Varnhagen (1956, v. I).

57. Ver Francisco Adolfo Varnhagen (1956, v. I, p. 301-302, 306-307, 318-319).

58. Ver Francisco Adolfo Varnhagen (1956, v. I, p. 199).

59. Ver Francisco Adolfo Varnhagen (1956, v. I, p. 235, 247, 257).

60. Tomé de Sousa, carta ao rei de 18 de julho de 1551 , dando conta dos trabalhos de Pero de Góis, original na Torre do Tombo: PT-TTCC-1-86-96.

61. Carlos Malheiro Dias (1921, p. 213) afirma que morreu no Brasil; e também que sua capitania tinha 50 léguas, quando na realidade são 30 . 
62. Ver Francisco Adolfo Varnhagen 1956 (v. II, p. 158).

63. Jaime Cortesão (1944, p. 57).

64. Em 12 de outubro de 1580, Jerônimo Leitão, locotenente de Lopo de Sousa, concede sesmarias em São Vicente, em seu nome.

65. Cf. Francisco Adolfo Varnhagen (1956, v. II, p. 34).
Góis da Silveira, que por ele e sua mulher foi "deixada" à Coroa em 1619, mediante uma tença ${ }^{b 2}$.

Cortesão afirma que em 1580, Pero de Góis já havia deixado de existir há muito, e que sua capitania pertencia a sua majestade ${ }^{63}$. Pela data do mapa e da morte de Pero de Góis, quem deveria figurar no mapa é seu filho, Gil de Góis da Silveira: mais uma informação defasada. Com relação à segunda parte da afirmação (pertencer a sua majestade), parece haver um erro, pelo menos de direito, se não de fato, pois o ano de 1619 estabelece a data oficial da posse da coroa.

O formato de sua capitania, no mapa de Luís Teixeira (comparar com o da Figura 5), não tem em conta a carta de doação do lote de São Vicente. Parece que também não teve acesso à carta de Pero de Góis pois estabelece o limite ao sul em Cabo Frio e não 13 léguas ao norte (rio Macaé).

Lopo de Sousa (São Vicente, Santo Amaro e Santana)

Martim Afonso de Sousa veio a falecer em 1571 ou 1572, ficando a capitania para seu primogênito Pedro Lopes de Sousa $\left(2 .^{\circ}\right.$ segundo donatário e praticamente homônimo de seu tio). Este acompanhou D. Sebastião na trágica batalha, e com ele faleceu em 1578. Sucede-the seu filho Lopo de Sousa (3. ${ }^{\circ}$ donatário), virtualmente nessa data ${ }^{64}$, ainda que a confirmação por parte de Felipe II seja tardia (1587). É ele que figura no mapa que examinamos. Por outro lado, como se viu, sua prima nomeou-o sucessor para os 3 lotes de Pero Lopes de Sousa, e assim ele acumulou Itamaracá e os dois lotes ao sul (Santo Amaro e Santana), situação que permaneceu até sua morte, em 15 de outubro de 1610. Sucede-the sua irmã, Mariana de Sousa Guerra, condessa de Vimieiro, ainda que um primo (Luis de Castro, conde de Monsanto e neto de Martim Afonso por parte de uma filha, D. Inês Pimentel) inicie a seguir uma longa e demorada demanda.

O relativo a ltamaracá já foi acima analisado. Com relação a Santana e as terras ao sul desta, embora o mapa de Luís Teixeira estenda os limites até o Prata, eles só chegavam até $28^{\circ} 1 / 3$, na altura aproximada da atual Laguna, sendo Cananeia o último local habitado. Desaparece acertadamente o lote de Pero Lopes de Sousa, conhecido como de Santo Amaro, encravado entre os dois lotes de São Vicente, pois tudo pertencia a Lopo de Sousa.

Mas a questão mais interessante é que nesse mapa aparece a cidade de São Sebastião, mas não a capitania do Rio de Janeiro. Como se viu, Mém de Sá sugeriu à Rainha a criação de outra "cidade real", como aquela do Salvador, e parece que ele contava com a aprovação real. Estácio de Sá, representando seu tio e governador-geral, na proclamação à véspera da batalha decisiva fala explicitamente da fundação de uma cidade. Por que não fala de povoação ou vila? É a questão prévia a dirimir.

Varnhagen sentiv essa mesma estranheza ao tratar da fundação de São Cristóvão do rio de Sergipe em 1590: "fundou um verdadeiro arraial, a que já deu o nome de cidade" 65 . Esse estranhamento surge de raciocinarmos com os 
padrões e a hierarquia de povoações que se forjou no século XVIII, presente nas legendas de muitos mapas dessa época, por exemplo, nos de Minas Gerais, em que se encontra o escalonamento: fazenda, capela, capela curada, vila e cidade, em função da população, da existência de pároco, de ter pelourinho, de ser a cabeça da capitania.

Mas na época em questão, a diferenciação não era essa. Com efeito, as cartas de doação enumeravam, entre os direitos do donatário, o de criar vilas; e a isso se atinham. Por sua vez, os governadores gerais, a partir de Tomé de Sousa, criavam cidades. A diferença estava, pois, na origem de quem criava o núcleo populacional: vilas pelos donatários e cidades reais pela coroa. Por isso, pequenos núcleos já nascem como cidades, por exemplo: São Cristóvão, Filipéia de Nossa Senhora das Neves, Cabo Frio, todos nascidos em torno de um forte erigido após a conquista aos índios e como proteção dos futuros ataques. Isso ocorreu também em todo o Norte, em uma progressiva conquista: Rio Grande, Ceará, Maranhão e Pará. Essa maneira, criar cidades reais, em torno de fortaleza e com a justificativa de defesa do território, foi a fórmula de ocupação territorial do Rio de Janeiro, passando por cima da autoridade e jurisdição do donatário.

Como possível contra-exemplo, poderia se citar o caso de Tomé de Sousa, que teria criado algumas vilas em São Paulo. Analisando com mais calma os documentos, em especial os de Frei Gasparbo, verifica-se que de fato este Governador sugeriu, indicou ou mesmo mandou que se estabelecessem algumas vilas, como por exemplo, Itanhaém, Santos e Santo André; mas fica bem claro que, depois de concluídas as obras de fortificação, Antonio de Oliveira, loco-tenente do donatário, acompanhado do provedor-mór da Fazenda (Brás Cubas), é quem sobe a serra e em nome do donatário levanta o pelourinho de Santo André 108 de abril de 1553), dá-the o título de vila e realiza as demais formalidades para a sua criação. Da mesma forma, Santos é erigida em vila em 1546 por Brás Cubas, loco-tenente de Martim Afonso ${ }^{67}$.

Por sua vez, o que Mém de Sá, por si ou por Estácio, criou, em nome da coroa, foi uma cidade fortificada para ocupar o território até então senhoreado por índios e franceses. Uma ocupação que se fazia necessária para manter a soberania portuguesa, sendo secundário ter sido isso feito em terras alheias. Aliás, Martim Afonso não se importaria com tal coisa; ao Conde de Castanheira, que the pedia alguma terra, respondeu: "mande-a tomar toda ou a que quiser, que essa será para mim a maior mercê e a maior honra do mundo" 68 .

Trabalho interessante, mas que foge ao escopo do presente, é a formação da capitania do Rio de Janeiro, não comprada pela coroa, mas ocupada de fato, com a solução do problema só acontecendo com D. Maria I, no final do XVIII69.

\section{Conclusão}

atlas de Luís Teixeira, além da cartografia propriamente dita, com seu rico conteúdo, contém abundância de informações históricas, presentes em sua
66. Ver Frei Gaspar da Madre de Deus (1975, p. 122).

67. Ibidem (p. 117).

68. Cf. Capistrano de Abreu nos prolegômenos à História de Frei Vicente do Salvador (1627, p. 106) a Carta de Martim Afonso, escrita em Diu, em 14 de dezembro de 1535 . Os próprios habitantes da capitania não se importariam tanto com isso; os moradores de Santos, desassistidos a certa altura, escrevem a Sua Majestade sugerindo que tome a capitania para si ou obrigue Martim Afonso ou um seu filho que venha governar a terra.

69. Ver Frei Gaspar (1780). 
cartela, nas divisões territoriais e nas vilas e cidades que mostra ou omite. Essas informações históricas e o texto do Roteiro aproximam-no muito de outros textos contemporâneos e que podem, em maior ou menor medida, serem considerados roteiros; em concreto, como se apontou, as obras de Gândavo (1574) e de Sousa (1587), e também da História de Frei Vicente do Salvador (1627). A proximidade se dá não só quanto às informações cartográficas e históricas, mas quanto ao conteúdo, estilo e forma de narrar. Um exemplo dessa semelhança é o local onde situam a linha de Tordesilhas ao sul (Baia de São Matias) e o sumidouro do rio São Francisco, presente nas obras textuais e no mapa: não existe tal acidente geográfico, mas pelo visto falava-se dele e isso se refletiu nas mencionadas obras e nessa cartografia.

Quer parecer-nos que essas obras cometem enganos por refletirem o conhecimento da época, um fundo comum de conhecimentos históricos e geográficos, que se vinha acumulando desde o descobrimento: notícias difundidas, história oral, narrativas que se transmitem de geração em geração; mas que são informações não comprovadas com o recurso a documentos originais (fontes primárias), como poderiam ser as cartas de doação e outros documentos de arquivos públicos. Talvez não estivessem mesmo disponíveis. E, além do mais, refletem o estado de desenvolvimento da ciência histórica: era necessário começar com obras do estilo de Frei de Vicente do Salvador, avançar com outras que consultam e citam as fontes, como as de Frei Gaspar ou Pedro Taques, passar pelos méritos e deficiências de um Varnhagen, antes de se chegar ao desenvolvimento de nosso tempo, que conta com bastantes fontes disponíveis, e que será superado mais adiante.

Nessa direção, Luís Teixeira desenhou as linhas divisórias das capitanias e consignou os donatários de acordo com aquilo que era voz corrente, conhecimento comum, geral e impreciso: as divisas correm para oeste. Também Anchieta, Frei Vicente e outros enganam-se com frequência ao tratar desses assuntos. Mas chama a atenção que um cartógrafo real, do porte de Luís Teixeira, não tivesse acesso a informações sobre os limites geográficos das divisões políticas, que é o principal tema de seu mapa, ou não tivesse conseguido produzir um mapa com maior exatidão. A quantidade de enganos é maior que a esperada.

Por tudo o que foi visto, para esse e para outros casos, há motivos para não considerar um mapa como um retrato fiel, uma "fotografia" da realidade em determinada data. É ou pode ser um documento histórico, como o são tantos outros, como os textos ou objetos arqueológicos, que deve ser lido com cuidado e sentido crítico. 


\section{REFERÊNCIAS}

BAIÃO, António. Boletim da segunda classe da Academia de Ciências de Lisboa, v. XI. Coimbra: Imprensa da Universidade, 1918.

Introdução ao Asia, de João de Barros, Coimbra: Imprensa da Universidade, 1932 (fac-símile reimpresso em 1988, p. XXVIII to XXXIX). Original no Arquivo da Torre do Tombo: CHR-L-1-21_c0151: ANTT, Chancelaria Régia, D. João III, Livro 21, folha 73.

CASTRO, Therezinha de. História documental do Brasil. Record: Rio de Janeiro, 1968.

CINTRA, Jorge Pimentel, Digital Cartography and Historical Maps: Techniques, Applications and Peculiarities. Revista Brasileira de Cartografia, Rio de Janeiro, v. 64, n. 6, p. 901-918, 2012. Disponível em: <http://www.lsie.unb.br/rbc/index.php/rbc/article/view/578>.

Reconstruindo o mapa das capitanias hereditárias. Anais do Museu Paulista: História e Cultura Material, São Paulo, v. 21, n. 2, p. 11-45, dez. 2013. Disponível em: <http://www. scielo.br/pdf/anaismp/v21n2/a02v21n2.pdf>.

Técnicas de leitura de mapas históricos: uma proposta. Revista Brasileira de Cartografia, Rio de Janeiro, v. 67, n. 4, p. 773-786, 2015

CORTESÃO, Jaime. Cabral e as origens do Brasil. Rio de Janeiro: Ministério das Relações Exteriores, 1944. Tomo I.

História do Brasil nos velhos mapas. Rio de Janeiro: Ministério das Relações Exteriores, 1965. Tomo I..

História do Brasil nos velhos mapas. 2 tomos. Lisboa: Imprensa Nacional-Casa da Moeda, 2009.

COSTA, Melba F. Roteiro de todos os sinais, conbecimentos, fundos, baixos, alturas, e derrotas que há na costa do Brasil...Lisboa: Tagol, 1988.

DIAS, Carlos Malheiro (Org.). História da colonização portuguesa do Brasil. Porto: Litografia Nacional, 1921. (v. 3).

GÂNDAVO, Pero Magalhães. Tratado da terra do Brasil: história da província da Santa Cruz... . Belo Horizonte: Itatiaia; São Paulo: Edusp, 1980. [1574].

GUEDES, Max Justo. Roteiro de todos os sinais da costa do Brasil. Rio de Janeiro: INL, 1968.

LEME, Pedro Taques de Almeida Pais. História da capitania de São Vicente. (Original de 1772). Brasília: Senado Federal, 2004. Disponível em: <http://www2.senado.leg.br/bdsf/ bitstream/handle/id/1087/690140.pdf?sequence $=4>$.

MADRE DE DEUS, Frei Gaspar da. Dissertação sobre as capitanias de Santo Amaro e São Vicente. (Original de 1780). Edição filológica Patricia Simone Ferucio Manoel Revisão Priscilla Uvo Morais. Biblioteca Nacional de Lisboa. Disponível em: <http://phpp.fflch.usp.br/sites/ phpp.fflch.usp.br/files/SIM\%C3\%95ES-MANOEL-MORAIS\%20(2013,\%20Eds.)\%20BNL_ COD11107_Frei\%20Gaspar_Disserta\%C3\%A7\%C3\%A3o_1780.pdf>. 
MADRE DE DEUS, Frei Gaspar da. Memórias para a história da capitania de São Vicente... São Paulo: Edusp, 1975. Primeira edição, de 1797, disponível em: <https://books.google.com. br/books?id=DI-Tzn-CDsAC\&printsec=frontcover\&hl=pt-BR\&source=gbs_ge_summary_r\&cad $=0{ }^{*} \mathbf{v}=$ onepage $\& q \& \mathrm{f}=$ false $>$.

MOTA, Avelino Teixeira da; CORTESÃO, Armando. Portugaliae monumenta cartographica. Lisboa: Imprensa Nacional Casa da Moeda, 1960.

PITA, Sebastião da Rocha. História da América Portuguesa. 3. ed. Salvador: Liv. Progresso, 1950. [1730].

SALVADOR, Frei Vicente do. História do Brasil: 1500-1627. 5. ed. São Paulo: Melhoramentos, 1965.

SOUSA, Gabriel Soares de. Tratado descritivo do Brasil em 1587. São Paulo: Nacional, 1971.

VARNHAGEN, Francisco Adolfo de. História geral do Brasil. 5. ed. São Paulo: Melhoramentos. 1956. (v. I). Primeira edição desse volume, de 1854, disponível em: <http://www.brasiliana. usp.br/bbd/handle/1918/01818710\#page/1/mode/1up>.

Artigo apresentado em 14/10/2015. Aprovado em 09/11/2015. 